\title{
Advanced in Molecular Mechanisms of Atherosclerosis: From Lipids to Inflammation
}

\author{
Anna Meiliana ${ }^{1,2, *}$, Nurrani Mustika Dewi ${ }^{2}$, Andi Wijaya ${ }^{1,2}$ \\ ${ }^{1}$ Postgraduate Program in Clinical Pharmacy, Padjadjaran University, Jl. Eijkman No.38, Bandung, Indonesia \\ ${ }^{2}$ Prodia Clinical Laboratory, Jl. Cisangkuy No.2, Bandung, Indonesia \\ *Corresponding author. E-mail: anna.meiliana@prodia.co.id
}

Received date: Jun 21, 2018; Revised date: Jul 24, 2018 ; Accepted date: Jul 31, 2018

\section{Abstract}

B ACKGROUND: Atherosclerosis is a leading cause of vascular disease worldwide. During the past several decades, landmark discoveries in the field of vascular biology have evolved our understanding of the biology of blood vessels and the pathobiology of local and systemic vascular disease states and have led to novel disease-modifying therapies for patients. This review is made to understand the molecular mechanism of atherosclerosis for these future therapies.

CONTENT: Advances in molecular biology and -omics technologies have facilitated in vitro and in vivo studies which revealed that blood vessels regulate their own redox milieu, metabolism, mechanical environment, and phenotype, in part, through complex interactions between cellular components of the blood vessel wall and circulating factors. Dysregulation of these carefully orchestrated homeostatic interactions has also been implicated as the mechanism by which risk factors for cardiopulmonary vascular disease lead to vascular dysfunction, structural remodeling and, ultimately, adverse clinical events.

SUMMARY: Atherosclerosis is a heterogeneous disease, despite a common initiating event of apoB-lipoproteins. Despite of acute thrombotic complications, an adequate resolution response is mounted, where efferocytosis prevents plaque necrosis and a reparative scarring response (the fibrous cap) prevents plaque disruption. However, a small percentage of developing atherosclerotic lesions cannot maintain an adequate resolution response, which leading to the formation of clinically dangerous plaques that can trigger acute lumenal thrombosis and tissue ischemia and infarction.

KEYWORDS: atherosclerosis, oxidative stress, inflammation, efferocytosis, foam cells, thrombosis

Indones Biomed J. 2018; 10(2): 104-22

\section{Introduction}

The burden of cardiovascular disease (CVD) has been risen to be a leading cause of morbidity and mortality despite the existence of statin and other preventive strategies to resolve it.(1,2) Simultaneously, many clinical researches had been performed to unravel the mechanisms and pathophysiology of atherosclerosis along with the clinical complications. These let us discover the development of new therapeutic approaches to combat CVD which is accompanied by so many advances and surprises.(3)
Gimbrone and García-Cardeña described the endothelial cells as a gatekeeper with barrier function, emerging the defender of vascular homeostasis.(4) Disturbances in antithrombotic, profibrinolytic, antiinflammatory and antioxidant properties of the normal endothelium lead to endothelial dysfunction and impairment of its vasodilator capacity.

Inflammation is entangled with traditional and emerging risk factors of atherosclerosis and its complication as a linked target pathways for developing therapies. Current large-scale study is applying weekly administration of low-dose methotrexate (MTX) or a monoclonal antibody 
(Mab) that neutralizes interleukin $1 \beta .(5,6)$ The point of this study is about applying anti-inflammatory intervention on the right spot that will quell the disease without impairing tumor surveillance or defenses against infection.(7)

Some studies affirmed the dynamic regulation to keep free cholesterol (FC) in cellular membrane micro domains and esterified cholesterol in lipid droplets in a balance state, which was regulated by lipoproteins and cellular cholesterol exporters. So, increasing FC in immune cells promotes receptor over sensitization that lead to inflammation, hematopoietic stem cell proliferation, leukocytosis and T-cell activation. Thus, these links of cellular cholesterol and inflammation are affecting not only atherosclerosis but also influence autoimmune diseases.(3)

The ascertainment of high-density lipoprotein (HDL) functions (such as cholesterol efflux potential), HDL particle number and therapeutic approaches that increase these variables faces challenges from disappointing results in many clinical studies and Mendelian randomization analyses.(8) Other approaches focusing on increasing the HDL function, using HDL mimetics to reverse transporting cholesterol or apolipoprotein A1 (apo A1) infusion, are also need to be reconsidered.

Recent studies on triglyceride-rich type lipoproteins and its pathogenicity have revitalized the enthusiasm for finding apolipoproteins V, apolipoproteins and C3, Angptl3 and Angptl4 as new therapeutic triglycerides targets or perhaps more specifically cholesterol-rich remnant lipoproteins. $(8,9)$ Genome-wide association studies and Mendelian randomization analyses brought up Lipoprotein (a) $(\mathrm{Lp}(\mathrm{a}))$ as a causative agent in atherothrombosis.(10) Another study found the role of noncoding small RNAs (micro-RNAs) as the power switch on atherosclerotic progression and regression as well as regression and lipid metabolism, which has opened entirely new vistas on the molecular pathways that control this disease.(11)

Then any availability of validated genetic markers proposes the possibility for applied risk stratification and personalized or precision medicine targeting therapy mode. $(10,11)$ Paynter, et al., proposed about the usefulness of genetic information in risk prediction and pharmacogenomic determinants of the response to therapies for atherothrombosis.(12) More studies were needed to bring those hypotheses from basic research to advance clinical application.(3)

We know that one size fits all approach is nowadays need to be developed into a smarter design. The goal of precision medicine in the future management of atherosclerotic risk in our patients could be achieved by using biomarkers and genetic information rationally to classify target therapies toward those who will most likely to benefit from the treatment. $(13,14)$

\section{Lipoproteins, Apolipoproteins and Atherosclerosis}

Today, it is no longer a hypothesis, but an established fact, that increased plasma concentrations of cholesterolrich apolipoprotein-B (apoB)-containing lipoproteins are causatively linked to atherosclerotic CVD and that lowering low-density lipoprotein (LDL) concentrations with statins and non-statins reduces atherosclerotic cardiovascular events in humans.(15-20) After decades of research, however, there is now a large body of evidence to support the response-to-retention hypothesis, which proposed that the key initiating event in atherogenesis is the retention, or trapping, of cholesterol-rich apoB-containing lipoproteins within the arterial wall. The retained lipoproteins and their byproducts provoke a series of strikingly maladaptive local responses that cause plaque initiation, growth, and evolution.(21)

The response-to-retention hypothesis, which was drew on work from the 1940s to the 1980s, shows that lipoproteins can interact with proteoglycans of the arterial wall.(22-25) Lipids and apoB are accumulated at lesion-prone sites before gross morphological changes occur.(26-29) Retention of apoB-lipoproteins is seen throughout the progression of atherosclerosis. The consequences of the retention of apoBlipoproteins include, not only an accumulation of lipid, but also prolonged exposure of these particles to local enzymes and other factors within the vessel wall. The retained and modified apoB-lipoproteins trigger cellular responses within the artery wall that accelerate further lipoprotein retention and lesion development.(30-32)

In earliest atherogenesis, negatively charged proteoglycans in the extracellular matrix of the arterial intima bind and trap apoB-lipoproteins via electrostatic interactions with specific positively charged aminoacyl residues in the full-length hepatic form of apoB, apoB100 (residues 3359-3369) (33), and in the truncated intestinal form, apoB48 (residues 84-94) (34). Moreover, apoB48lipoproteins typically contain numerous molecules of apoE, an apoprotein that has a proteoglycan-binding domain almost identical to the proteoglycan-binding sequence in apoB100. Proteoglycans are negatively charged due to the sulfate and carboxylic acid groups in their GAG side-chains. Lipoproteins normally flux into and out of the arterial 
wall. $(28,35)$ The molecular mediators of this transendothelial movement of lipoproteins remain incompletely characterized. Recent evidence has suggested roles for caveolin-1 $(36,37)$ and the scavenger receptor class B type I (SR-BI) (38). Following retention of cholesterol-rich apoB-lipoproteins within the artery wall, the lipoproteins have been shown to undergo several modifications with important biological consequences (Figure 1).

Aggregated apoB-lipoproteins are avidly taken up by macrophages $(30,39)$ and by vascular SMCs $(40)$ and lead to foam-cell formation. These processes stimulate the release of proatherogenic factors that induce the synthesis of proteoglycans with enhanced affinity for atherogenic lipoproteins.(30,39) In addition, monocyte/ macrophages recruited into atheromata secrete proretentive enzymes, notably lipoprotein lipase, sphingomyelinase and PLA2, that accelerate further retention of atherogenic lipoproteins.(21)

Key enzymes implicated in apoB-lipoprotein retention, aggregation, and atherogenesis include the secretory sphingomyelinase (S-SMase), lipoprotein lipase, and the non-pancreatic secretory group $\mathrm{V}$ phospholipase-A2 (PLA2-V).(30,41-45) These enzymes, particularly lipoprotein lipase, are bridging between LDL and proteoglycans independently of the physical state of apoB and thereby cause a shift in the retentive mechanism from a low-affinity process (apoB-GAG binding) in the pristine arterial wall to a high-affinity process (lipoprotein-GAG binding) in an established atheroma. This shift in retentive mechanism has direct clinical consequences. A lifetime plasma LDL cholesterol concentration of $80 \mathrm{mg} / \mathrm{dL}$ will almost always protects from atherosclerosis (46), but the pre-existing plaques will grow if the LDL-cholesterol is 80 $\mathrm{mg} / \mathrm{dL}$ (47).

In the context of the response-to-retention hypothesis, roles for HDL in every step have been hypothesized. (48) Those roles include interfering with the irreversible binding of plasma LDL to arterial wall proteoglycans (49$51)$, blocking SMase-induced aggregation of $\operatorname{LDL}(52,53)$, removing toxic lipids and resolving the maladaptive inflammatory infiltrate (54-58). Along these lines, the apoA-I mimetic peptide $4 \mathrm{~F}$ was recently shown to block SMaseinduced LDL aggregation and the increase in binding of the modified LDL particles to human aortic proteoglycans. (59) In contrast, abnormal HDL or apoA-I within the arterial wall may have adverse effects. $(53,60-62)$ Using our extensive knowledge of the pathogenesis of atherosclerosis, we can now reclassify nearly all epidemiologic risk factors into causative agents, exacerbating factors and bystander phenomena.(63) Causative and exacerbating factors are targets for therapy, meanwhile bystander phenomena are not.

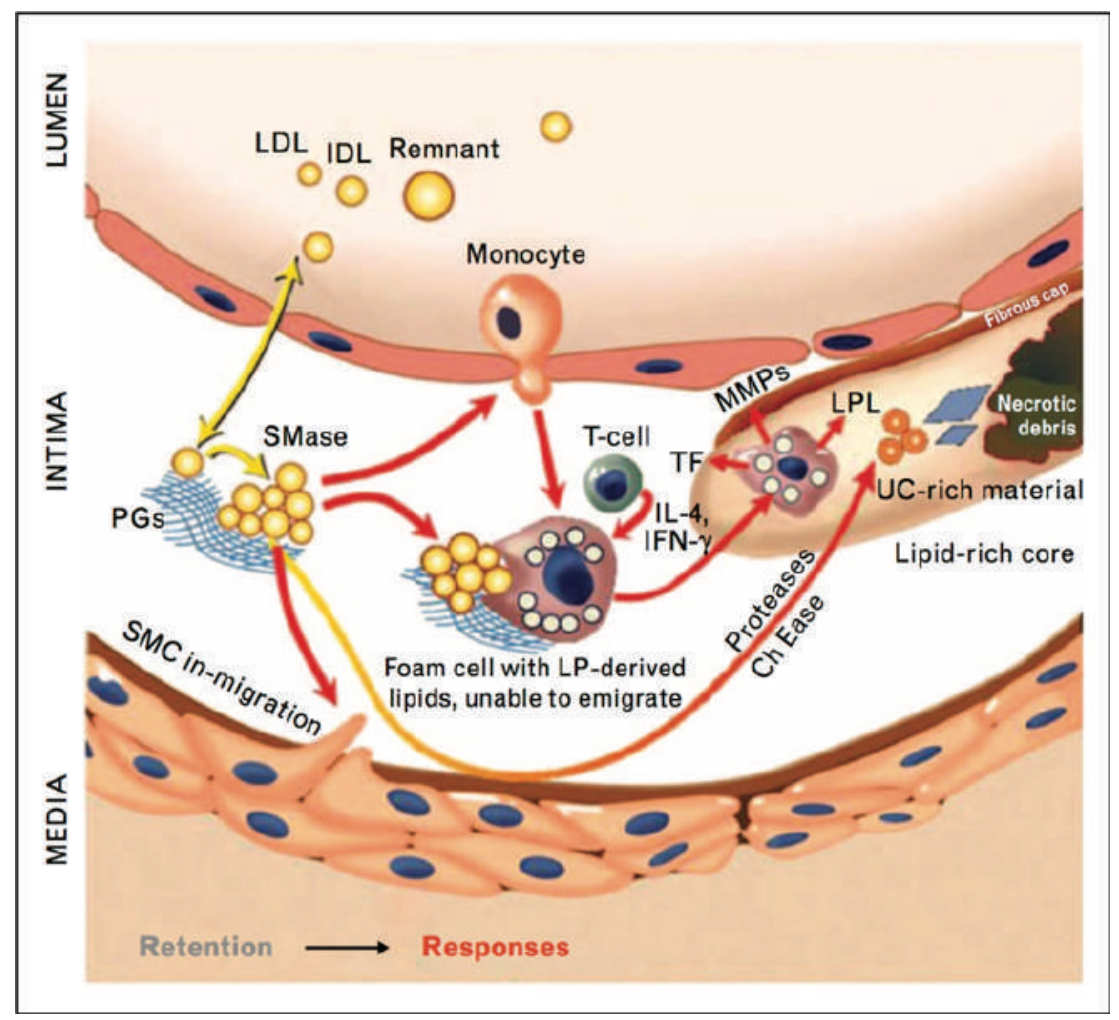

Figure 1. The response-to-retention model of initiation and progression of atherosclerosis.(21) (Adapted with permission from Wolter Kluwer Health). 


\section{Oxidative Stress, Inflammation and Atherosclerosis}

Key steps in the atherosclerosis process include the accumulation and oxidation of LDLs by reactive oxygen species (ROS) within the artery wall accompany with persistent inflammatory process via infiltration of monocyte-macrophages, forming foam cells on uptake of oxidized LDL (ox-LDL). This process sooner or later can result in rupture or erosion of the arterial wall, forming thrombus and subsequent platelet aggregation called atherothrombosis, which resulting in blood flow occlusion and downstream cellular damage. The involvement of ROS in atherothrombosis process is including nitric oxide (NO) inactivation or NO synthase inhibition and platelet activation via overexpression of platelet eicosanoids and platelet NO inhibition, which finally contribute to the arterial dysfunction. $(64,65)$

Besides LDL, sphingolipids are also proven to have a potent biological effects in atherosclerotic process. Ceramides are a group of sphingolipids generated from hydrolysis of sphingomyelin by sphingomyelinases, neutral sphingomyelinases, and acidic sphingomyelinases (A-SMase). By the activation of sphingomyelinases, ox-LDL increases the production of ceramides. $(53,66)$ Then sphingomyelinase-dependent hydrolysis of LDLsphingomyelin become a potential pathway for ceramide accumulation in atherosclerotic plaques.(53) Compared to healthy vascular tissue, glycosphingolipids, such as glucosylceramide and lactosylceramide, which are generated from ceramides have also been found higher in human atherosclerotic plaque. $(67,68)$ Both lactosylceramide and ceramide through the action of neutral sphingomyelinase were involved in cell apoptosis (69-71), but lactosylceramide has been suggested to contribute in plaque formation by stimulating cell proliferation in human aortic smooth muscle cells $(72,73)$. Not only associated with, but also suggested to induce plaque inflammation and instability, sphingolipids especially glucosylceramide open up opportunities to be a novel therapeutic targets.

Lipid rafts, microdomains, or nanodomains, different in sizes from 5- to 500-nm-diameter structures, could be highly ordered formed regularly from glycerophospholipids, sphingomyelin and FC, but not cholesteryl ester (CE). (74-76) Membrane rafts are small heterogeneous, highly dynamic, sterol- and sphingolipid-enriched domains that compartmentalize cellular processes.(76) They are detergent-resistant membrane complexes rich in FC. FC serve as the raft stabilizer through hydrophobic binding to the other components. Lipid raft commonly present in two types, planar lipid raft and invaginated one, with caveolar or little cave whose structure depends on the caveolin proteins that are unique to caveolae. Cholesterol is an essential component of both lipid rafts and caveolae.(77-81)

To maintain lipid raft, cells require FC. Excess FC for this purpose will be stored in the cytoplasm as CE. When the influx of cholesterol is greater than the outflow, the accumulation of CE droplets and foam cell formation occurs. Otherwise, loss of foam cell cholesterol will occur. Thus, high value of EC/total cholesterol ratio implies cell progression, whereas a low value implies foam cell regression.(82) Lipid raft must be carefully regulated so the microdomains or nanodomains are able to provide a platform for organizing the signaling of many receptors and proteins, including the B-cell receptor, T-cell receptor (83-85) and major histocompatibility class receptors $(86,87)$. The cholesterol used to form and maintain lipid raft can be obtained from exogenous sources, such as lipoproteins, especially LDL, or from endogenous cellular synthesis via the mevalonate pathway in the endoplasmic reticulum followed by transport to the plasma membrane, or from the intracellular lipid droplets. $(88,89)$ From lipid droplets, cholesterol will move out with help of extrinsic signals promoting the hydrolysis of CE by cholesterol ester hydrolases. $(90,91)$ FC also can be used for cellular membrane maintenance, unless it will be moved to a substrate pool for export via ABCA1. $(92,93)$ The membrane cholesterol that regulates lipid raft composition, controlled by ABCA1 under the regulation of the liver X receptor.(94)

Modified lipoproteins, such as ox-LDL, enhance endothelial damage that trigger leukocyte recruitment, which eventually fail to clear lipoproteins, undergo cell death, and contribute to inflammation. Ultimately, growing lesions will lead to vessel occlusion and subsequent ischemia or (arterial) thrombosis. $(95,96)$ After long time been denied, neutrophils and their specific contribution in atherosclerosis pathophysiology, recent studies present substantial evidences about the actions of neutrophils in early and established human and murine atherosclerotic lesions.

Suicidal neutrophils expel become neutrophil extracellular traps (NET), which consist of a complex structure of nuclear chromatin and proteins of nuclear, granular and cytosolic origin. They have a net-like structures which also found in atherosclerotic lesions and arterial thrombi in humans and mice. Functionally, NET can induce pro-inflammatopry immune response via activation 
of endothelial cells, antigen-presenting cells and platelets. Thus, NET not only presents in plaques and thrombi but also plays a causative role in triggering atherosclerotic plaque formation and arterial thrombosis in any stage of diseases progression, especially where there are high local concentration of pro-inflammatory effector molecules.(97) The present neutrophil-derived proteases and ROS lead to plaque destabilization.(98-100)

Atherosclerosis is a chronic lipid-driven, maladaptive and non-resolving inflammatory disease of the vessel wall. Over several decades, atherosclerosis progresses in indolence and silence, eventually resulting in the formation of a life-threatening, rupture-prone atherosclerotic plaque. (101-103) In brief, the disease is triggered by subendothelial retention of infiltrated LDL into the intimal space. The accumulated LDL undergoes oxidation and aggregation in the intima, presenting a source of chronic stimuli that instigate and propagate an innate immune reaction.
This includes the recruitment, homing, migration and differentiation of monocytes into macrophages that avidly phagocytose modified cholesterol, secrete pro-inflammatory cytokines, enzymes and ROS and eventually undergo cell death. Together, these processes and the defective clearance of the dying cell propagate the inflammatory response, forming a vulnerable atherosclerotic plaque. The key characteristics of a vulnerable plaque include a very thin fibrous cap encapsulating acellular necrotic core regions, lipid-laden macrophages and $\mathrm{T}$ lymphocytes and sometimes, intraplaque hemorrhage.(104) Figure 2 shows macrophage apoptosis, autophagy and necroptosis in atherosclerosis.

Necroptosis is a new term for a type of programmed necrosis besides apoptosis and autophagic. Current findings demonstrate that macrophage necroptosis directly contributes to necrotic core formation and plaque instability. Pro-resolving mediators have been shown to promote the inflammation resolution and enhance efferocytosis, thus

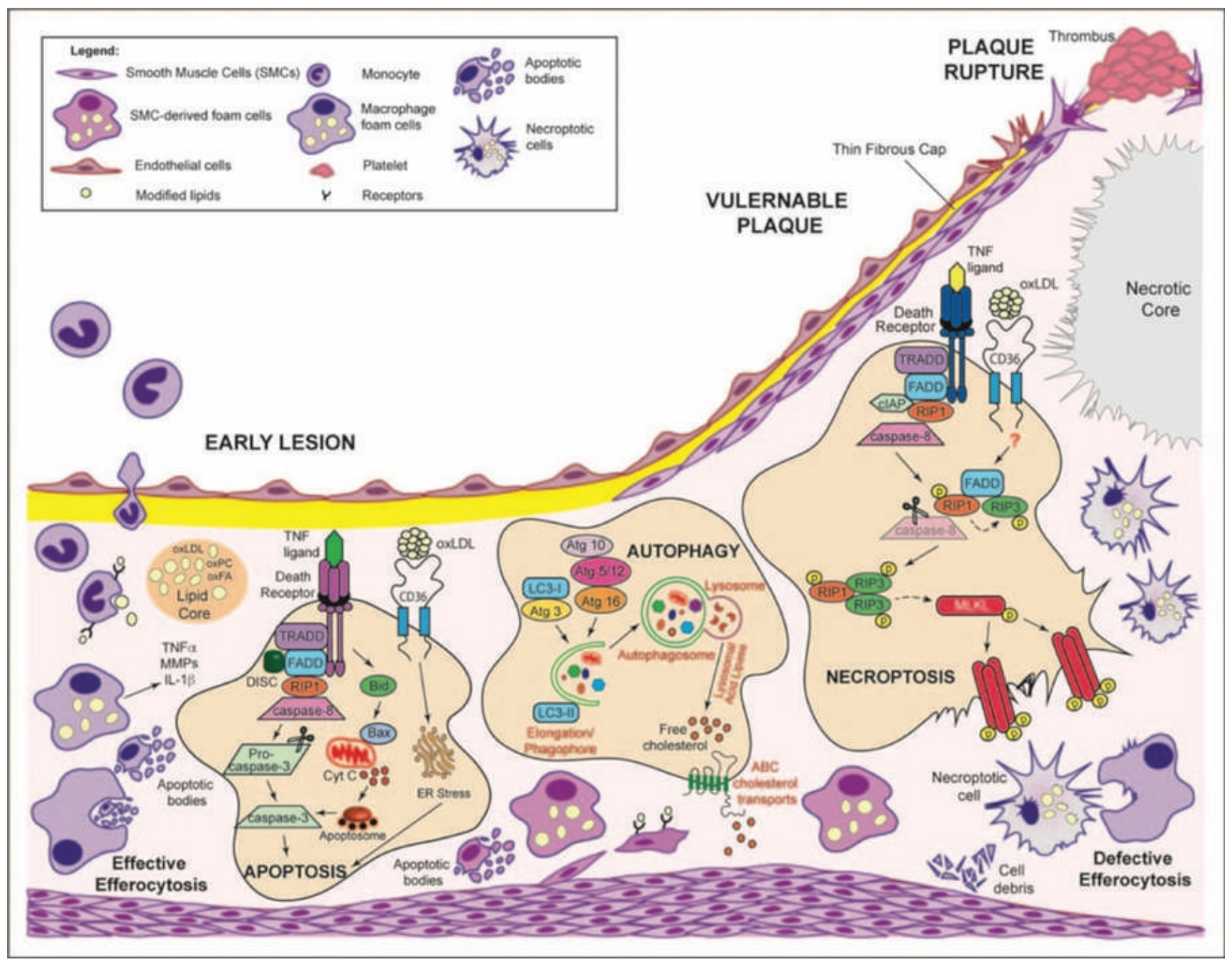

Figure 2. Macrophage apoptosis, autophagy and necroptosis in atherosclerosis.(105) (Adapted with permission from Wolter Kluwer Health). 
decrease plaque vulnerability. Otherwise, the canonical 'don't eat me' signal cluster of differentiation (CD)47 plays a role in impairing efficient efferocytosis then progress the atherosclerotic lesion.(105) Improving our understanding of the mechanisms that regulate macrophage death in atherosclerosis (apoptosis, necroptosis and efferocytosis) will provide novel therapeutic opportunities to resolve atherosclerosis and promote plaque stability.(105)

\section{Endothelial, Vascular Smooth Muscle Cells and Atherosclerosis}

Endothelial cell dysfunction (ECD) on the lesion-prone covering areas of the arterial vasculature contributes in the pathobiology of atherosclerotic CVD. ECD covers a constellation of various non-adaptive alterations in functional phenotype, that regulating hemostasis and thrombosis, local vascular tone and redox balance, also the orchestration of acute and chronic inflammatory reactions within the arterial wall.

ECD manifest as the earliest detectable changes on lesion-prone areas of the arterial vasculature in atherosclerotic lesion progression, in form of focal permeation, trapping, and physicochemical modification of circulating lipoprotein particles in the subendothelial space.(106-108) These pathogenic sequence commenced by selective recruitment of circulating monocytes from the blood into the intima.(107-113) They differentiate into macrophages and internally modified lipoproteins become foam cells, endothelium and macrophages will be activated in elaboration with multiple chemokines and growth factors, and induce the nearby smooth muscle cells (or their precursors) proliferation and extracellular matrix components synthesis within the intimal compartment, finally generating a bromuscular plaque.(114)

Developing lesions involve a continuous structural remodeling, which result in fibrous cap, overlying a lipidrich, necrotic core consisting of oxidized lipoproteins, cholesterol crystals and cellular debris. Matrix remodeling and calcification varying degrees also play a role in this complicated plaques, along with a rich population of inflammatory cells (activated macrophages and $\mathrm{T}$ cells, natural killer $\mathrm{T}$ cells and dendritic cells), modulating the endothelial proinflammatory phenotype and proteolytic modification of its extracellular matrix component, provide the plaques' structural instability.(115-117) When the plaque is unstable or vulnerable, frank plaque rupture, with luminal release of the highly thrombogenic contents of the necrotic core, an atherothrombotic occlusion could be triggered.(118-121) Evidently, superficial intimal erosions without plaque rupture also make a consequence of significant clinical sequelae, suggested due to endothelial cell apoptosis, with localized endothelial denudation and the triggering of thrombus formation. $(4,122)$

By this angle, the vascular endothelium can be regarded as a dynamically adaptable interface distributed organ, and at individual cell level, an integrator of the local pathophysiological milieu. Thus, dysfunction endothelial certainly alter its normal functional phenotype non-adaptively, entangle the regulation of hemostasis and thrombosis (123), local vascular tone (124) and redox balance (125), also induce the orchestration of acute and chronic inflammation (124). Thus, the term endothelial cell dysfunction was proposed into the mainstream of atherosclerosis research $(126,127)$, and the molecular manifestations of ECD began to be characterized in detail. $(117,121,124,128)$

Several studies documented that Kruppel-like factor 2 (KLF2) expression in endothelial cells promotes an anti-inflammatory, antithrombotic endothelial phenotype, due to its antagonism of the nuclear factor kappa-B (NF$\kappa B)$ pathway.(129) KLF2 regulates the functions of other endothelial cells, making it important for atherogenesis, including endothelial barrier function (130), metabolism (131) and the release of miRNAs via the shedding of endothelial microvesicles (132). It also stimulates the production of several autocoids, including $\mathrm{NO}$ and C-type natriuretic peptide, which were found to be deficient in dysfunctional endothelium in vivo.(133) Study showed that mice genetically deficient in KLF2 enhanced atherosclerotic plaque formation compared to wild-type controls.(134)

Nuclear factor erythroid 2-related factor-2 (Nrf2), activated by atheroprotective flow in cultured endothelial cells, via the phosphoinositol 3-kinase/ Akt and extracellular signal-regulated protein kinase 5 pathways, counted to have an atheroprotector properties. Nrf2 controls a subsequential of target genes that play a role in the regulation of intracellular redox balance, as well as resistance to extracellular oxidant stress.(135-137) Nrf2 in vivo expressed differentially in those relatively atherosclerosis-resistant regions of the vasculature, suggesting its pathophysiological relevance. $(135,138)$

Current studies reported the independent act of KLF2 and $\mathrm{Nrf} 2$ in the activation of flow-mediated gene expression, with a requirement for KLF2 expression for full activity of Nrf2 antioxidant vasoprotection-mediated. $(139,140)$ These 2 transcription factors are pointed as master regulators of the 
vasoprotective endothelial phenotype (4), as they counted for $\approx 70 \%$ of the atheroprotective flow-induced endothelial transcriptome activation.(141)

Protein modifications with small ubiquitin-like modifier (SUMO) have been found to play a key role in regulating the formation of atherosclerosis.(141-143) SUMO proteins covalently modify certain residues of specific target substrates and change the function of these substrates. It has been well established that the protein inhibitor of activated signal transducer and activator of transcription (STAT) family of proteins has not only SUMO E3 ligase activity, but also transrepression activity.(144) Lerchenmüller, et al., assume that this may be one of the regulatory mechanisms by which interferon-inducible transmembrane protein 1 (IFITM1) can inhibit endothelial cell proliferation.(145) Some studies performed postmortem and/or by imaging have identified some plaque instability characteristic that could lead to rupture: 1) a thin or fragmented fibrous cap with smooth muscle $\alpha$-actin (ACTA2)-positive cells, guess to be derived from vascular smooth muscle cells (VSMCs); 2) CD68 or galectin-3 positive cells found in a large mass, suspect to be macrophages; and 3) necrotic core containing cells filled with lipid (foam cells) found in a large numbers, suspect to be macrophages.(146)

These was correlated with the general dogma that bulks of macrophages and macrophage-derived foam cells relative to VSMCs found in atherosclerotic plaque, particularly within the fibrous cap and shoulder regions, are less stable and more prone to rupture. $(107,147)$ Thus, VSMCs in advanced lesions could generally regarded as the atheroprotective plaque-stabilizer, while macrophages are regarded to promote atherosclerosis and detriment the plaque stabilization. VSMC can phenotypically switching, and this is affecting the plaque stability. Inhibiting VSMC phenotypic switching regulation may be beneficial in advanced atherosclerosis, suggest this could be a chance to replace these more conventional antiatherosclerotic therapies.(146)

\section{MicroRNA and Circadian Control in Atherosclerosis}

Both immune and non-immune cellular constituents of the vessel wall were involved in many stages of the pathogenesis of atherosclerotic lesion formation. Over decades many studies strive to uncover any key signaling and molecular regulatory pathways involve in the plaque initiation and progression. MiRNA provides novel molecular insights on atherosclerosis progressive pathways, and is reported to have an important role in regulating many pathophysiological processes, such as cellular adhesion, proliferation, lipid uptake and efflux, also generation of inflammatory mediators. The appreciation of miRNAs detection extracellularly including in circulating blood make a hike in its potential as new tool for diagnosis, prognosis, or in response to cardiovascular therapeutics.(11)

MiRNAs are a small ( $\approx 18-24$ nucleotides), evolutionary conserved, single-stranded noncoding RNAs that regulate $>60 \%$ gene expression, either reducing protein expression by blocking mRNA translation and by promoting mRNA degradation at the post-transcriptional level by typically binding to the 3 '-untranslated region (UTR) of specific target mRNA sequences, using a conserved $\approx 7-8$ nucleotide seed sequence.(148-152) Moreover, one miRNA can bind to and regulate $>1$ target, even as a part of the same signaling pathway, also can harbor several distinct miRNA-binding sites within its 3 '-UTR, adding multiple levels of regulation. Recent studies reported of LDL and HDL abundance and function controlled by miRNAs, have greatly expanded our understanding of the regulatory circuits governing plasma lipoprotein levels.

MiR-148a is negatively regulating LDL-C plasma levels by targeting the LDL receptor (LDLR) and is showed to increase the clearance of circulating labeled LDL and decrease plasma LDL-C levels.(153,154) Some miRNAs, such as miR-33 (155-159), miR-758 (160), miR-26 (161), miR-106 (162), miR-144 (163,164), miR-128-118 and miR148a (154), play role in regulating HDL biogenesis and cholesterol efflux by controlling the levels of plasma HDL-C and the reverse cholesterol transport pathway by targeting ATP-binding cassette transporter (Figure 3). ABCA1 plays a central role in these processes by controlling cholesterol efflux across the cell membrane onto lipid-poor apoA1 (155), and mediate both hepatic HDL biogenesis and the removal of excess cholesterol from peripheral cell including macrophages in atherosclerotic plaques.

The cholesterol homeostasis in macrophages is maintained by the balance between cholesterol uptake, endogenous synthesis, esterification/hydrolysis and efflux. miR-27a/b, which is involved in this lipoprotein homeostasis, regulates the cholesterol in macrophage via genes involved in cholesterol esterification (ACAT1), uptake (LDL and CD36), and efflux (ABCA1).(165) While miR-125a-5p and miR-146a decrease lipid uptake and cytokine release in ox-LDL-stimulated macrophages, via oxysterol binding protein-like 9 and toll-like receptor (TLR)4 genes, respectively.(166,167) Furthermore, miR- 


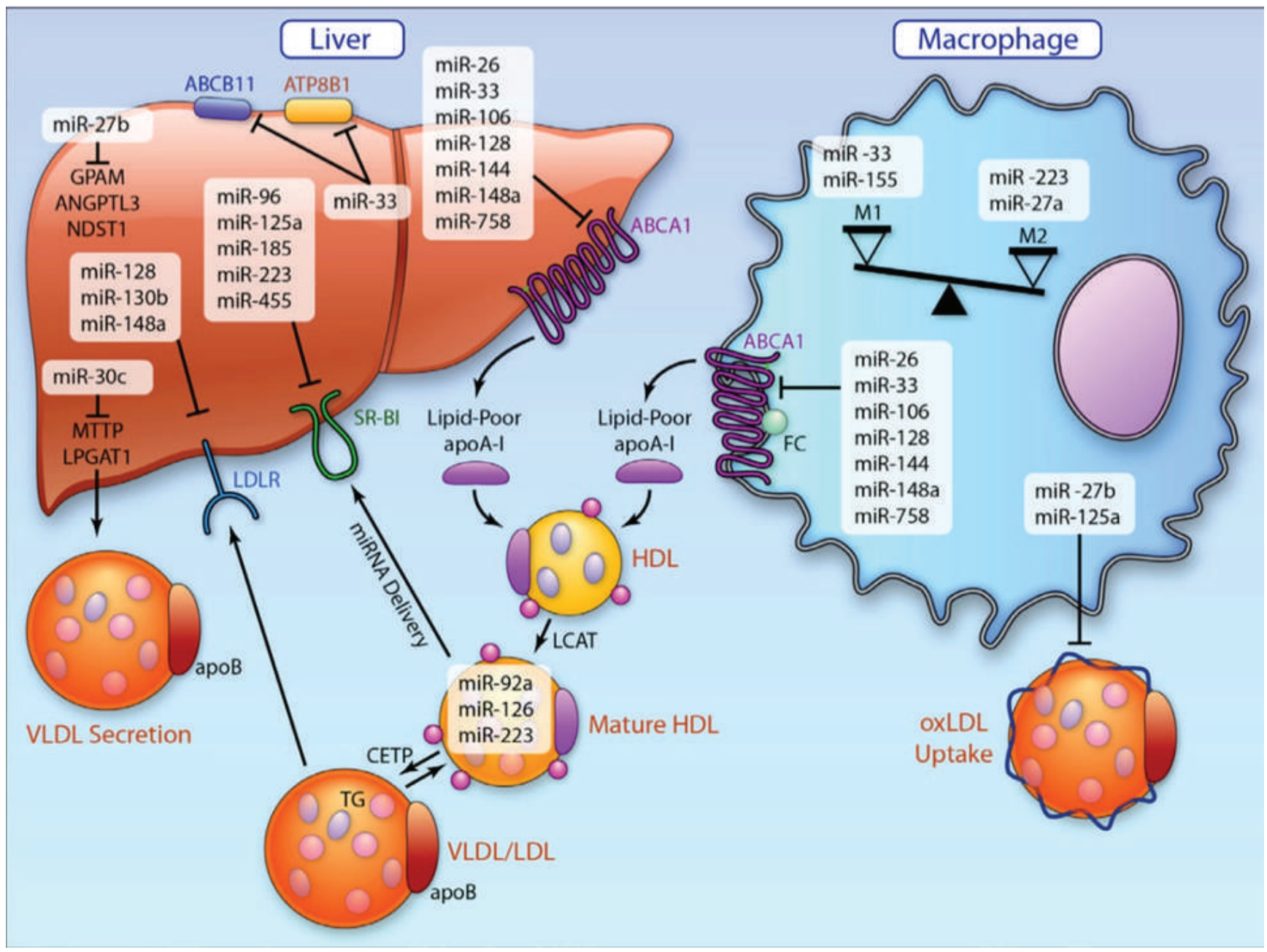

Figure 3. MicroRNA (miRNA) orchestration of cholesterol homeostasis and macrophage activation in atherosclerosis.(11) (Adapted with permission from American Heart Association).

155 plays a role in macrophage foam cell formation by negatively regulates macrophage inhibitory factor, via the transcriptional repressor HMG box-transcriptional protein 1, a protein known to increase the uptake of ox-LDL by macrophages.(168)

Circulating miRNA can be detected in peripheral blood, saliva and urine, so their expression may be harbingers of a range stages of CAD from subclinical atherosclerotic disease to acute coronary syndromes.(11) miRNAs may have enormous effects on biological pathways, cell function and homeostasis in the vessel wall, liver and periphery. Experimenting a MiRNA mimics or inhibitors may offer an attractive therapeutic approach for atherosclerotic disease in specific stages and the management of its complications.

Circadian rhythms refer to 24 hours biological process that endogenously, entrainable oscillation, which adjust behavior and physiological activities to environmental changes. This involves daily rhythmicity such as regulation of sleep-wake cycles, feeding, body temperature, blood pressure, heart rate, hormone secretion, metabolism (including lipid metabolism), and many other biological functions. $(169,170)$ Our circadian clock is set by the brain's suprachiasmic nucleus, which interprets recurring external stimuli, and autonomous molecular networks in peripheral cells together. When circadian clock is disrupted or misaligned, multiple pathologies, including chronic inflammatory and metabolic diseases such as atherosclerosis could rise.(171)

Some studies suggest a circadian oscillations of circulating counts of leukocytes, or at least immune cell numbers involved in atherosclerosis (Figure 4).(172) Emerging evidence suggests that circadian rhythms play an important role in vascular function and health. Circadian rhythms not only influence systemic atherosclerosis mediators, including leukocytes and lipids, but also locally control cells within the vessel wall. Studies conducted 


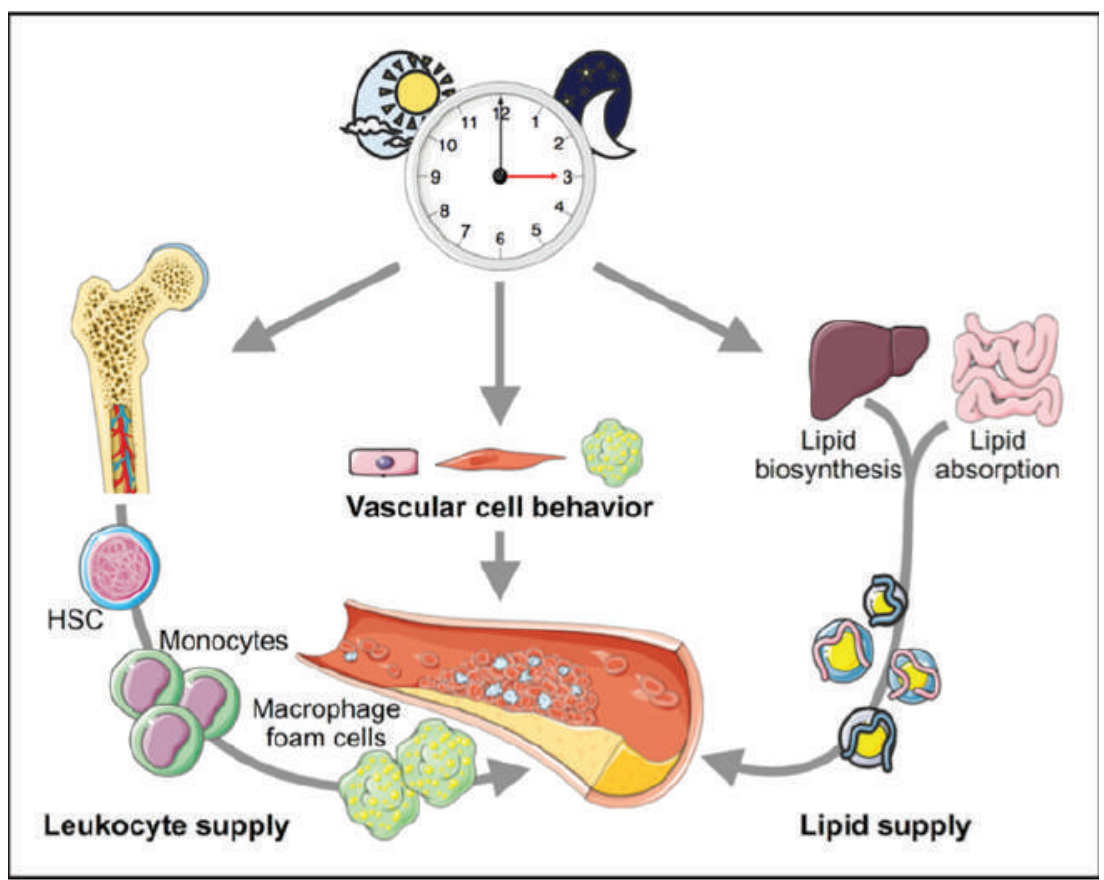

Figure 4. Circadian influence on atherosclerosis.(171) (Adapted with permission from American Heart Association).
$>15$ years ago demonstrated the existence of a functional circadian clock in the vasculature.(173-175) It was found that among 330 genes, $5 \%$ to $10 \%$ of the transcriptome, exhibit circadian expression patterns in mouse aortae.(176) Circadian patterned genes include those related to the core molecular clock, lipid and glucose metabolism, protein folding, and vascular integrity.

VSMC from human carotid plaque exhibits lower amplitudes of mRNA expression levels of core clock genes compared to normal carotid smooth muscle cells from same donors. This rose a notion about the role of mismatching circadian gene expression patterns toward the central clocks in atherosclerotic vessels, that might play a role in plaque stability.(177) Some evidences showed that brain and muscle Arnt-like protein-1 (BMAL1)-dependent peripheral circadian clocks in immune cells have a role in inflammatory markers expression, such as C-C motif chemokine ligand 2 (CCL2).(178) Studies in atherosclerotic mouse models indicated the importance of the CCL2 and $\mathrm{C}-\mathrm{C}$ motif chemokine receptor (CCR2) axis in early lesion development. CCL2 or its corresponding receptor CCR2 genetic deficiency leads to a reduction in lesion development with lower monocyte/macrophage content in the lesion.(179,180) Indicate that the CCL2-CCR2 axis in atherogenesis as a result of mobilization and homeostasis of classical monocytes under steady state rather than their recruitment.(181) Circadian clock gene perdiod 2 (PER2) deficiency promotes aortic endothelial dysfunction (182), which is the initial stage of lesion development.
We can conclude that circadian rhythmicity plays an important role in atherosclerosis progressive by influencing atherosclerotic plaque development, either by central clock or many peripheral clocks existed. Cell-intrinsic molecular clocks found in leukocytes, endothelial cells, macrophages and SMC have been identified to be linked to inflammatory processes underlying atherosclerotic lesion development. (183) A better understanding of the link between circadian rhythms and cardiovascular pathologies might help developing more targeted and personalized therapeutic strategies for cardiovascular disease patients.

\section{Gut Microbiota in Atherosclerosis}

New and emerging technologies are continue to reveal that the microbiome plays a critical role in the maintenance of vascular health and in the development of vascular disease. The diversity of the human microbiome between individuals, in both species and patterns of colonization, may underlie the differential phenotypic expression of vascular disease and ultimately establish a new paradigm in personalized medicine.(184) The Human Microbiome Project used nextgeneration DNA sequencing to identify thousands of distinct bacterial species that are resident in and on the normal human body. The aggregate number of bacteria far exceeds the total number of human cells and accounts for $1 \%$ to $3 \%$ of the total body mass (i.e., $0.7-2.1 \mathrm{~kg}$ in a $70-\mathrm{kg}$ person). DNA sequence analysis also revealed that microbes residing 
in different anatomic sites such as the gut, skin, respiratory tract and genitourinary system are characterized by distinct enzymatic pathways that are adapted to metabolize nutrients present in the local environment.(185)

To understand the mechanisms by which the microbiome regulates vascular function, metabolomic profiling was used to identify specific bacteria-derived molecules related to energy metabolism and vascular homeostasis. Further analysis identified trimethylamine as the gut metabolite and bacteria-derived chemical with the clearest association with cardiovascular disease.(186) In clinical studies, unbiased metabolic profiling further revealed a significant increase in the levels of trimethylamine-Noxide (TMAO) and related metabolites in plasma samples from patients with increased risk for CVD compared with matched control subjects.(187) TMAO is formed by bacterial metabolism of choline and phosphatidylcholine in the gut to yield trimethylamine, which is oxidized in the liver by the enzyme flavin monooxygenase-3 to form TMAO. (187) TMAO has become the target of several therapeutic interventions, ranging from schemes to reduce dietary intake of trimethylamine precursors to manipulations of the gut microbiome to reduce trimethylamine synthesis. The revelation regarding atherosclerosis susceptibility that could be transmitted from an atherosclerosis-prone strain of mice to another strain typically resistant to atherosclerosis simply by the transplantation of gut microbes provided additional causal evidence to support the role of the gut microbiome in regulating atherosclerosis (Figure 5).(188)

Studies of the gut microbiome in rodent models show that in response to changes in dietary intake of carbohydrates, fat, and fiber, there are changes in the gut microbiota at the phylum level. Similar studies in humans have shown the same trend, but there is significant interindividual variability. There is also regional variability in the microbiome, and the diversity and composition can reflect an industrialized versus agrarian diet. Thus, it may be possible to predict disease risk vis-à-vis diets rich in phosphatidylcholine, a source of choline, or dietary carnitine, which is ultimately metabolized to TMAO.(189)

At present, the causal pathways and molecular mechanisms whereby the gut microbiome initiates and perpetuates cardiopulmonary vascular disease remain incompletely characterized. However, early studies in the field indicate that future in vitro and in vivo studies of the blood vessel function must now contend with an additional layer of complexity in experimental design. These studies will need to examine local and remote interaction with the gut microbiota and metabolites. For in vitro studies often done in the presence of antibiotics, this remains a challenge. Further adding to the experimental complexity, the microbiome may be altered by diet and by drugs. Thus, in addition to standardizing diets for in vivo studies, the effects of drugs (and delivery vehicle) will need to be evaluated. (184)

\section{Gut Microbiota in Atherosclerosis}

Cell senescence describes the irreversible inability of a previously proliferative cell to proliferate, despite adequate mitogen stimulation. Cell senescence is a fundamental

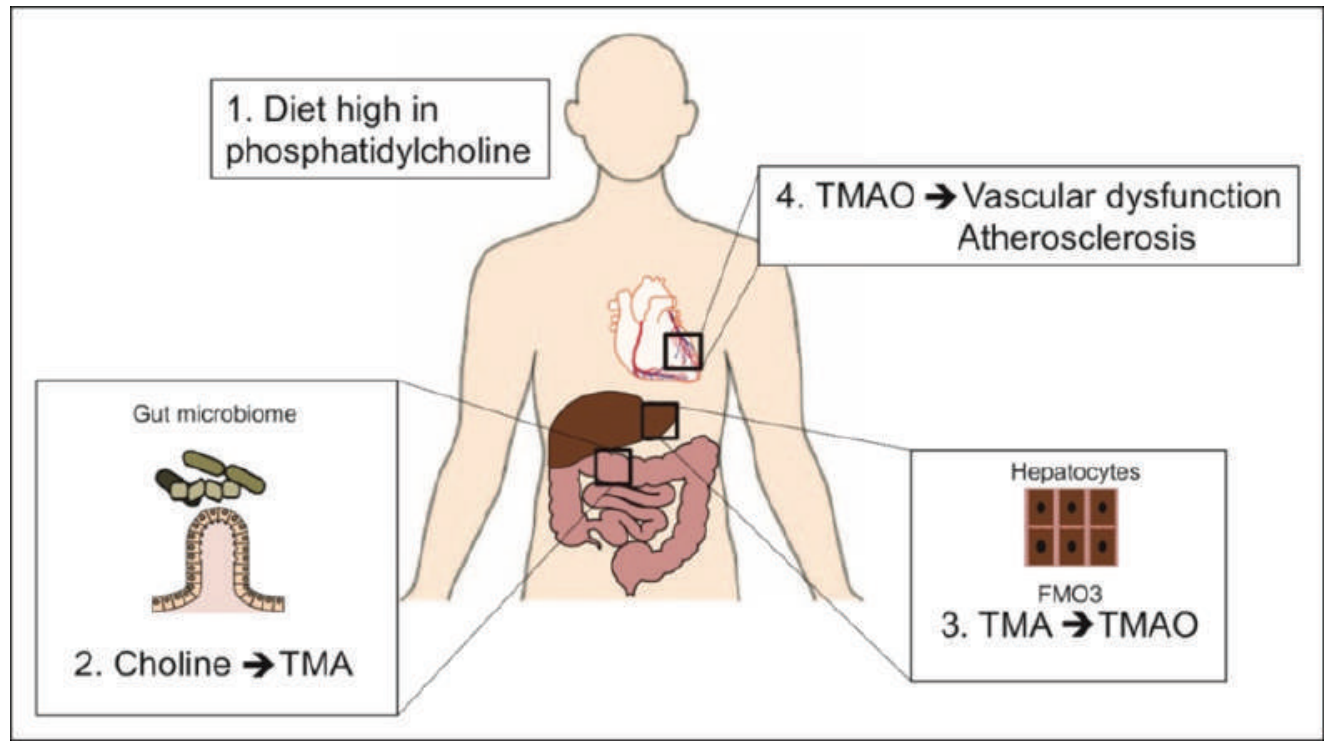

Figure 5. The gut microbiome and atherosclerosis.(184) (Adapted with permission from American Heart Association). 
process underlying normal biological ageing and agedrelated degeneration of multiple tissues. However, recent studies have identified that cell senescence is also part of normal tissue remodeling, for example during development, as a process that regulates tissue mass and architecture.(190) Cellular senescence induces an evolutionarily conserved senescence-associated secretory phenotype (SASP), resulting in release of inflammatory cytokines, chemokines and proteases.(191) The SASP may be beneficial, for example attraction of immune cells to clear senescent cells (192-195) and tumor suppression (196,197). However, a persistent SASP may be deleterious, promoting cell proliferation (197), angiogenesis through increased vascular endothelial growth factor (VEGF) expression (198), epithelial-to-mesenchymal transformation and invasiveness of premalignant epithelial cells (199). The role of the SASP in atherosclerosis remains largely unknown, although the SASP of human senescent VSMCs requires interleukin (IL)- $1 \alpha$, and causes both endothelial cell dysfunction and mononuclear cell recruitment (200).

Telomere erosion in endothelial cells is increased in vessels prone to develop atherosclerosis $(201,202)$, and the telomeres are shorter in VSMCs in human plaques compared with non-atherosclerotic vessels from the same donor (203). However, telomere shortening is not just a marker of senescence, but also promotes senescence, plaque development and features of unstable plaques. For example, telomere uncapping in VSMCs by forced expression of a dominant-negative telomeric repeat-binding factor 2 (TRF2) protein accelerates atherogenesis, increases necrotic core and reduces fibrous cap areas.(204) This suggests that dysfunctional telomeres predispose to both initiation and progression of atherosclerosis.(205) The effects of cell senescence in atherosclerosis clearly depend upon the cell type being affected. Senescent endothelial cells also accumulate in vessels with age $(202,206)$ and in atherosclerosis $(207,208)$, which may importantly contribute to age-accelerated atherogenesis.

Senescent endothelial cells are dysfunctional and have reduced and uncoupled endothelial NO synthase (eNOS) activity, resulting in enhanced superoxide anion production and decreased NO bioavailability.(208,209) Senescent endothelial cells also exhibit increasing inflammatory responses, which include enhanced expression of vascular cell adhesion molecule-1 (VCAM-1) and intercellular adhesion molecule-1 (ICAM-1) (208,210), and also develop a SASP characterized by increased IL-6 and IL-8. Senescence, eNOS uncoupling and the SASP are regulated in part by p38a mitogen-activated protein kinase (MAPK), S6-kinase (S6K) and arginase II (211).
The senescence markers include elevated senescenceassociated $\beta$-galactosidase (SA $\beta$-Gal) activity and p16Ink4a, p53 and p21 expression. $(208,212)$ However, whether and how senescent cells contribute to atherogenesis remains unclear.(213,214) Human plaques contain cells with shortened telomeres, which predispose cells to undergo senescence.(204) Consistent with a proatherogenic role of senescence, the expression of a loss-of-function TRF2 in VSMCs accelerates plaque growth in the $\mathrm{ApoE}^{-/}$ mouse model of atherosclerosis, although in vivo evidence for increased senescence in plaques was not provided. (215) Importantly, senescent cells are metabolically and synthetically active, producing numerous factors that are released locally called senescence-messaging secretome or senescence-associated secretory phenotype. Interestingly, plasminogen activator inhibitor-1 (PAI-1) has been identified as a prominent member of the senescencemessaging secretome.(214) PAI-1 is a validated marker of cellular senescence (Figure 6).

PAI-1 is not a mere marker of cellular senescence but also a key mediator of cellular senescence and a major contributor to the multi-morbidity of aging.(216) The almost ubiquitous presence of cell senescence in atherosclerosis and the fundamental role of senescence in regulating plaque development and stability suggest that prevention or amelioration of senescence in atherosclerosis is a viable therapeutic target.(190)

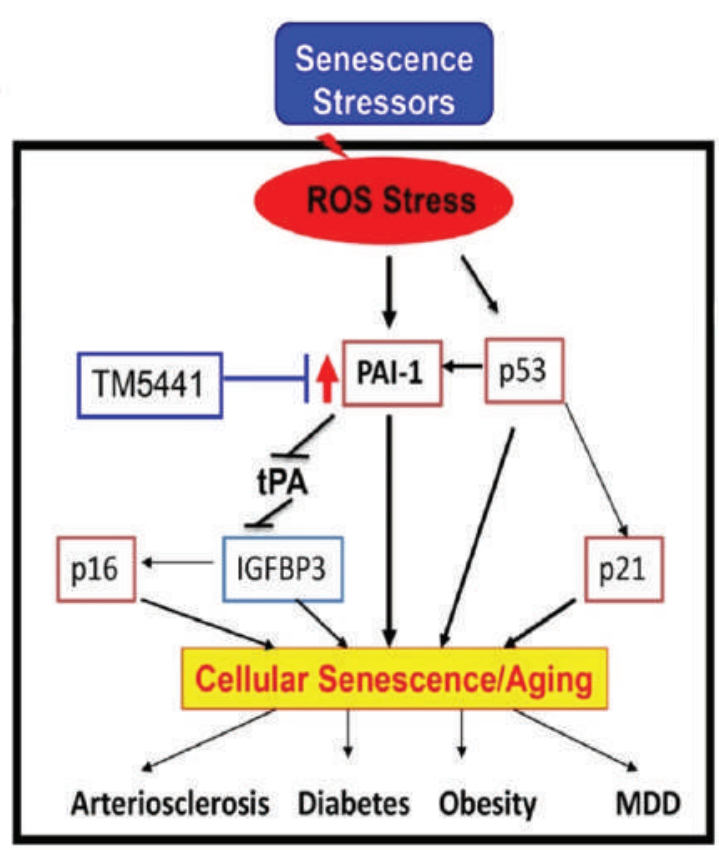

Figure 6. Molecular involvement of PAI-1 (plasminogen activator inhibitor-1) in cellular senescence and associated diseases.(216) (Adapted with permission from American Heart Association). 


\section{Genetics and Precision Medicine in Atherosclerosis}

Coronary artery disease (CAD) has important genetic underpinnings considered equivalent to that of environmental factors. The heritability of CAD has been estimated between $40 \%$ and $60 \%$, on the basis of family and twin studies, a method that yields high precision despite potential bias.(10) Precision medicine is an approach to disease treatment and prevention that seeks to maximize effectiveness by taking into account individual variability in genes, environment and lifestyle. One central aim of the recently launched US Precision Medicine Initiative is the return of genetic results for clinical utility.(217) The major clinical and biochemical atherosclerosis risk factors for coronary heart disease (CHD) and other forms of CVD have been well defined over the past 50 years by prospective population cohorts like the Framingham Heart Study and resulting randomized, controlled treatment trials (RCTs). Genetics for CVD risk prediction provides the opportunity to more precisely identify individuals at high risk for developing disease for whom preventive therapy can be directed.(218)

Our initial understanding regarding genetic risk for myocardial infarction and other forms of CHD has focused on rare $(<1: 100$ carrier rate) monogenic etiologies conferring exceptional risk, such as mutations in genes LDLR, proprotein convertase subtilisin/kexin type 9 (PCSK9), or ApoB underlying the predisposition for familial hypercholesterolemia.(219-222) However, because of the efforts of international consortia over the past decade, genome wide association studies of hundreds of thousands of research participants have led to the discovery of more than 50 common (>1:20 carrier rate) gene variants with strong evidence for modest increases in CHD risk, and $>150$ common genetic variants with strong evidence for modest alterations of levels of key lipid fractions.(223) An individual's CHD genetic risk score (GRS) is an additive score of the burden of discovered CHD risk alleles that is often weighted by the estimated disease effect of each allele.

Nevertheless, in a recent post hoc analysis of RCTs of statin therapy for primary and secondary prevention of CHD, persons with the highest burden of CHD risk alleles were not only at increased risk for CHD events, but also, surprisingly, experienced enhanced absolute and relative clinical benefit despite similar LDL-cholesterol lowering. (224) These data suggest that a CHD GRS may identify people at increased risk who may be more likely to benefit from preventive interventions.
The evidence of CHD not only affected by environmental factors, genetics factor play an important role as rising the risk to 2- until 3-fold in one's personal with parental history of premature CHD.(225) Some observational epidemiological studies showed that plasma LDL (assessed as LDL-C and TRLs), HDL (assessed as HDL-C), triglyceride-rich lipoproteins (TRLs), and Lp(a), all been found to be correlated with CHD risks.(226-228) About one half of the interindividual variation in plasma lipid concentrations attributable to genetic variants.(229) $\mathrm{Lp}(\mathrm{a})$ is an LDL-like particle that is covalently linked to a protein called apolipoprotein(a). Lp(a) level in plasma could varies up to 1000 -fold determined by genetic variation.(230) Mendelian randomization studies found that genetically elevated Lp(a) results in increased risk of CHD.(231,232) Then, it was suggested that decreasing plasma Lp(a) may have a cardiovascular protective effect.

Lipoprotein-associated phospholipase A2 (LpPLA2) is an enzyme that is encoded by the phospholipase A2 group VII (PLA2G7) gene. Circulating Lp-PLA2 in plasma primarily associated with LDL particles, and thus its mass and activity is also associated with CHD risk.(233) Darapladib, an inhibitor of Lp-PLA2 in Stabilization of Atherosclerotic Plaque by Initiation of Darapladib Therapy (STABILITY) trial and The Stabilization Of pLaques usIng Darapladib-Thrombolysis In Myocardial Infarction 52 Trial (SOLID-TIMI 52) found that darapladib did not reduce the risk of CHD (234,235), dubious the Lp-PLA2 as a causal risk factor for disease.

CHD follow-up studies have demonstrated roles for many other genes involved in CHD. Lysosomal acid lipase A (LIPA), sortilin 1 (SORT1) and tribbles homolog 1 (TRIB1) act as plasma lipid regulators in the liver, as well as in macrophages biology. Transcription factor 21 (TCF21) within the vessel wall is upregulated in dedifferentiated smooth muscle cell, migrate to form fibrous cap. Adamts7 is also a regulator of smooth muscle migration but also suggested to role the endothelial cells (Figure 7).(236)

The past decade of research has provided a broader understanding of the genetic architecture of CAD and demonstrates that the genetic basis of CAD largely derives from the cumulative effect of multiple common risk alleles individually of small effect size rather than rare variants with large effects on CAD risk. Although traditional risk factors remain important, application of these data using a systems genetics approach has pointed to substantial roles for genes and pathways relevant to vessel wall biology and immune function.(10) 


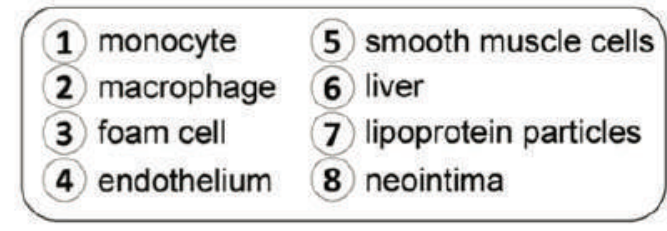

(2) macrophage

3 foam cell

(4) endothelium
(1) monocyte
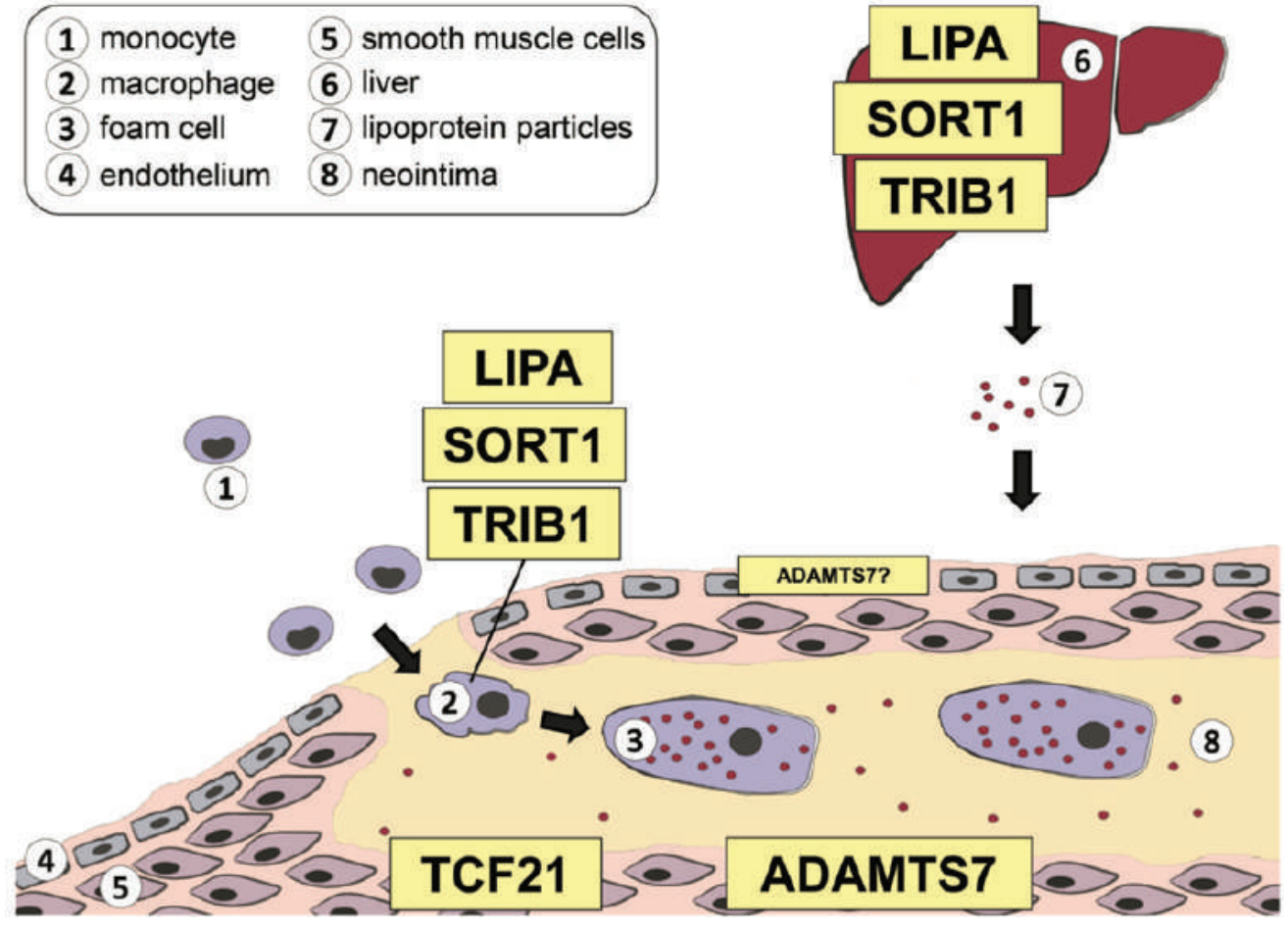

Figure 7. Coronary heart disease (CHD) genomewide association studies (GWAS) risk genes are active in selective cell types involved in atherosclerosis. (236) (Adapted with permission from American Heart Association).

\section{Conclusion}

Cardiovascular system homeostasis is sustained by the genetic and epigenetic interacting programs. Any disequilibrium will cause a complex stream of pathogenesis such as atherosclerosis and its life-threatening complications, myocardial infarction and stroke. Atherosclerosis is a chronic inflammatory disease that is initiated by the retention and accumulation of cholesterol-containing lipoproteins, particularly low-density lipoprotein, in the artery wall. In the arterial intima, lipoprotein components that are generated through oxidative, lipolytic and proteolytic activities lead to the formation of several danger-associated molecular patterns, which can activate innate immune cells as well as vascular cells. Moreover, self- and non-self-antigens, such as $\mathrm{ApoB}$ and heat shock proteins, can contribute to vascular inflammation by triggering the response of $\mathrm{T}$ and $\mathrm{B}$ cells locally. This process can influence the initiation, progression and stability of plaques. There are several uncertainties and challenges about the role of genetics in the management and prevention of chronic disease. The focus on precision medicine aims to catalyze an effort to better understand human disease biology, and optimize disease treatment and prevention by using a combination of clinical, biochemical, and genetic factors.

\section{References}

1. Brown MS, Goldstein JL. Heart attacks: gone with the century? Science. 1996; 272: 629. doi: 10.1126/science.272.5262.629.

2. Mozaffarian D, Benjamin EJ, Go AS, Arnett DK, Blaha MJ, Cushman M, et al. Heart Disease and Stroke Statistics-2016 Update: A Report From the American Heart Association. Circulation. 2016; 133: e38360.

3. Libby P, Bornfelt KE, Tall AR. Atherosclerosis. Success, surprises, and future challenges. Circulation. 2016; 116: 531-4.

4. Gimbrone MA Jr, Garcia-Cardena G. Endothelial cell dysfunction and the pathobiology of atherosclerosis. Circ Res. 2016; 118: 62036.

5. Ridker PM, Howard CP, Walter V, Everett B, Libby P, Hensen $\mathrm{J}$, et al. Effects of interleukin- $1 \beta$ inhibition with canakinumab on hemoglobin A1c, lipids, C-reactive protein, interleukin-6, and brinogen: a phase IIb randomized, placebo-controlled trial. Circulation. 2012; 126: 2739-48.

6. Everett BM, Pradhan AD, Solomon DH, Paynter N, Macfadyen J, Zaharris E, et al. Rationale and design of the Cardiovascular In ammation Reduction Trial: a test of the in ammatory hypothesis of atherothrombosis. Am Heart J. 2013; 166: 199-207.e15.

7. Libby P, Tabas I, Fredman G, Fisher EA. In ammation and its resolution as determinants of acute coronary syndromes. Circ Res. 2014; 114: 1867-79.

8. Musunuru K, Kathiresan S. Surprises from genetic analyses of lipid risk factors for atherosclerosis. Circ Res. 2016; 118: 579-85.

9. Nordestgaard BG. Triglyceride-rich lipoproteins and atherosclerotic cardiovascular disease: new insights from epidemiology, genetics, and biology. Circ Res. 2016; 118: 547-63.

10. McPherson R, Tybjaerg-Hansen A. Genetics of coronary artery disease. Circ Res. 2016; 118: 564-78. 
11. Feinberg MW, Moore KJ. MicroRNA regulation of atherosclerosis. Circ Res. 2016; 118: 703-20.

12. Mega JL, Stitziel NO, Smith JG, Chasman DI, Caulfield MJ, Devlin $\mathrm{JJ}$, et al. Genetic risk, coronary heart disease events, and the clinical benefit of statin therapy: an analysis of primary and secondary prevention trials. Lancet. 2015; 385: 2264-71.

13. Paynter NP, Ridker PM, Chasman DI. Are genetic tests for atherosclerosis ready for routine clinical use? Circ Res. 2016; 118: 607-19.

14. Herrington W, Lacey B, Sherliker P, Armitage J, Lewington S. Epidemiology of atherosclerosis and the potential to reduce the global burden of atherothrombotic disease. Circ Res. 2016; 118: 535-46.

15. Mihaylova B, Emberson J, Blackwell L, Keech A, Simes J, Barnes $\mathrm{EH}$, et al. The effects of lowering LDL cholesterol with statin therapy in people at low risk of vascular disease: meta-analysis of individual data from 27 randomised trials. Lancet. 2012; 380: 58190 .

16. Cannon CP, Blazing MA, Giugliano RP, McCagg A, White JA, Theroux $\mathrm{P}$, et al. Ezetimibe added to statin therapy after acute coronary syndromes. N Engl J Med. 2015; 372: 2387-97.

17. Robinson JG, Farnier M, Krempf M, Bergeron J, Luc G, Averna $\mathrm{M}$, et al. Efficacy and safety of alirocumab in reducing lipids and cardiovascular events. N Engl J Med. 2015; 372: 1489-99.

18. Sabatine MS, Giugliano RP, Wiviott SD, Raal FJ, Blom DJ, Robinson $\mathrm{J}$, et al. Efficacy and safety of evolocumab in reducing lipids and cardiovascular events. N Engl J Med. 2015; 372: 1500-9.

19. Hegele RA, Gidding SS, Ginsberg HN, McPherson R, Raal FJ, Rader DJ, et al. Nonstatin low-density lipoprotein - lowering therapy and cardiovascular risk reduction-statement from ATVB Council. Arterioscler Thromb Vasc Biol. 2015; 35: 2269-80.

20. Williams KJ, Tabas I, Fisher EA. How an artery heals. Circ Res. 2015; 117: 909-13.

21. Boren J, Williams KJ. The central role of arterial retention of cholesterol-rich apolipoprotein-B-containing lipoproteins in the pathogenesis of atherosclerosis: a triumph of simplicity. Urr Opin Lipidol. 2016; 27: 473-83.

22. Faber M. The human aorta; sulfate-containing polyuronides and the deposition of cholesterol. Arch Pathol. 1949; 48: 342-50.

23. Camejo G, Lopez A, Vegas H, Paoli H. The participation of aortic proteins in the formation of complexes between low density lipoproteins and intima media extracts. Atherosclerosis 1975; 21: 77-91.

24. Iverius PH. The interaction between human plasma lipoproteins and connective tissue glycosaminoglycans. J Biol Chem. 1972; 247: 2607-13.

25. Vijayagopal P, Srinivasan SR, Radhakrishnamurthy B, Berenson GS. Interaction of serum lipoproteins and a proteoglycan from bovine aorta. J Biol Chem 1981; 256: 8234 -41.

26. Smith EB, Slater RS. Lipids and low density lipoproteins in intima in relation to its morphological characteristics. Ciba Found Symp. 1973; 12: 39-62.

27. Tamminen M, Mottino G, Qiao JH, Breslow JL, Frank JS, Ultrastructure of early lipid accumulation in ApoE-deficient mice. Arterioscler Thromb Vasc Biol. 1999; 19: 847-53.

28. Schwenke DC, Carew TE. Initiation of atherosclerotic lesions in cholesterol-fed rabbits. II. Selective retention of LDL vs. selective increases in LDL permeability in susceptible sites of arteries. Arteriosclerosis. 1989; 9: 908-18.

29. Nakashima Y, Fujii H, Sumiyoshi S, Wight TN, Sueishi K. Early human atherosclerosis: accumulation of lipid and proteoglycans in intimal thickenings followed by macrophage infiltration. Arterioscler Thromb Vasc Biol. 2007; 27: 1159-65.
30. Williams KJ, Tabas I. The response-to-retention hypothesis of early atherogenesis. Arterioscler Thromb Vasc Biol. 1995; 15: 55161.

31. Williams KJ, Tabas I. Lipoprotein retention--and clues for atheroma regression. Arterioscler Thromb Vasc Biol. 2005; 25: 1536-40.

32. Borén J, Gustafsson M, Skålén K, Flood C, Innerarity TL. Role of extracellular retention of low density lipoproteins in atherosclerosis. Curr Opin Lipidol. 2000; 11: 451-6.

33. Borén J, Olin K, Lee I, Chait A, Wight TN, Innerarity TL. Identification of the principal proteoglycan-binding site in LDL. A single-point mutation in apo-B100 severely affects proteoglycan interaction without affecting LDL receptor binding. J Clin Invest. 1998; 101: 2658-64.

34. Flood C, Gustafsson M, Richardson PE, Harvey SC, Segrest JP, Borén $\mathrm{J}$. Identification of the proteoglycan binding site in apolipoprotein B48. J Biol Chem. 2002; 277: 32228-33.

35. Sloop CH, Dory L, Roheim PS. Interstitial fluid lipoproteins. J Lipid Res. 1987; 28: 225-37.

36. Frank PG, Pavlides S, Cheung MWC, Daumer K, Lisanti MP. Role of caveolin-1 in the regulation of lipoprotein metabolism. Am J Physiol Cell Physiol. 2008; 295: C242-8

37. Fernández-Hernando C, Yu J, Suárez Y, Rahner C, Dávalos A, Lasunción MA, et al. Genetic evidence supporting a critical role of endothelial caveolin-1 during the progression of atherosclerosis. Cell Metab. 2009; 10: 48-54.

38. Armstrong SM, Sugiyama MG, Fung KY, Gao Y, Wang C, Levy AS, et al. A novel assay uncovers an unexpected role for SR-BI in LDL transcytosis. Cardiovasc Res. 2015; 108: 268-77.

39. Tabas I, Williams KJ, Boren J. Subendothelial lipoprotein retention as the initiating process in atherosclerosis: update and therapeutic implications. Circulation. 2007; 116: 1832-44.

40. Lao KH, Zeng L, Xu Q. Endothelial and smooth muscle cell transformation in atherosclerosis. Curr Opin Lipidol. 2015; 26: 44956.

41. Bostrom MA, Boyanovsky BB, Jordan CT, Wadsworth MP, Taatjes DJ, de Beer FC, et al. Group V secretory phospholipase A2 promotes atherosclerosis: evidence from genetically altered mice. Arterioscler Thromb Vasc Biol. 2007; 27: 600-6.

42. Oorni K, Kovanen PT. PLA2-V: a real player in atherogenesis. Arterioscler Thromb Vasc Biol. 2007; 27: 445-7

43. Gustafsson M, Levin M, Skalen K, Perman J, Friden V, Jirholt P, et al. Retention of low-density lipoprotein in atherosclerotic lesions of the mouse: evidence for a role of lipoprotein lipase. Circ Res. 2007; 101: 777-83.

44. Devlin CM, Leventhal AR, Kuriakose G, Schuchman EH, Williams KJ, Tabas I. Acid sphingomyelinase promotes lipoprotein retention within early atheromata and accelerates lesion progression. Arterioscler Thromb Vasc Biol. 2008; 28: 1723-30.

45. Tabas I, Li Y, Brocia RW, Xu SW, Swenson TL, Williams KJ. Lipoprotein lipase and sphingomyelinase synergistically enhance the association of atherogenic lipoproteins with smooth muscle cells and extracellular matrix. A possible mechanism for low density lipoprotein and lipoprotein(a) retention and macrophage foam cell formation. J Biol Chem. 1993; 268: 20419-32.

46. Cohen JC, Boerwinkle E, Mosley TH Jr, Hobbs HH. Sequence variations in PCSK9, low LDL, and protection against coronary heart disease. N Engl J Med. 2006; 354: 1264-72.

47. Nissen SE, Tardif JC, Nicholls SJ, Revkin JH, Shear CL, Duggan WT, et al. Effect of torcetrapib on the progression of coronary atherosclerosis. N Engl J Med. 2007; 356: 1304-16.

48. Williams KJ. What does HDL do? A new mechanism to slow atherogenesis - but a new problem in type 2 diabetes mellitus. Atherosclerosis. 2012; 225: 36-8. 
49. Bihari-Varga M. Influence of serum high density lipoprotein on the low density lipoprotein-aortic glycosaminoglycan interactions. Artery. 1978; 4: 504-9.

50. Camejo G, Cortez MM, Lopez F, Starosta R, Mosquera B, Socorro L. Factors modulating the interaction of LDL with an arterial lipoprotein complexing proteoglycan: the effect of HDL. Acta Med Scand Suppl. 1980; 642: 159-64.

51. Umaerus M, Rosengren B, Fagerberg B, Hurt-Camejo E, Camejo G. HDL2 interferes with LDL association with arterial proteoglycans: a possible athero-protective effect. Atherosclerosis. 2012; 225: 11520

52. Sneck M, Nguyen SD, Pihlajamaa T, Yohannes G, Riekkola ML, Milne R, et al. Conformational changes of apoB-100 in SMasemodified LDL mediate formation of large aggregates at acidic $\mathrm{pH}$. $\mathrm{J}$ Lipid Res. 2012; 53: 1832-9.

53. Schissel SL, Tweedie-Hardman J, Rapp JH, Graham G, Williams KJ, Tabas I. Rabbit aorta and human atherosclerotic lesions hydrolyze the sphingomyelin of retained low-density lipoprotein. Proposed role for arterial-wall sphingomyelinase in subendothelial retention and aggregation of atherogenic lipoproteins. J Clin Invest. 1996; 98 : 1455-64.

54. De Nardo D, Labzin LI, Kono H, Seki R, Schmidt SV, Beyer $\mathrm{M}$, et al. High-density lipoprotein mediates anti-inflammatory reprogramming of macrophages via the transcriptional regulator ATF3. Nat Immunol. 2014; 15: 152-60

55. Moore KJ, Fisher EA. High-density lipoproteins put out the fire. Cell Metab. 2014; 19: 175-6.

56. Hewing B, Parathath S, Barrett T, Chung WKK, Astudillo YM, Hamada $\mathrm{T}$, et al. Effects of native and myeloperoxidasemodified apolipoprotein A-I on reverse cholesterol transport and atherosclerosis in mice. Arterioscler Thromb Vasc Biol. 2014; 34: $779-89$.

57. Niyonzima N, Samstad EO, Aune MH, Ryan L, Bakke SS, Rokstad $\mathrm{AM}$, et al. Reconstituted high-density lipoprotein attenuates cholesterol crystal-induced inflammatory responses by reducing complement activation. J Immunol. 2015; 195: 257-64.

58. Bursill CA, Castro ML, Beattie DT, Nakhla S, van der Vorst E, Heather AK, et al. High-density lipoproteins suppress chemokines and chemokine receptors in vitro and in vivo. Arterioscler Thromb Vasc Biol. 2010; 30: 1773-8.

59. Nguyen SD, Javanainen M, Rissanen S, Zhao H, Huusko J, Kivelä AM, et al. Apolipoprotein A-I mimetic peptide 4F blocks sphingomyelinase-induced LDL aggregation. J Lipid Res. 2015; 56: 1206-21.

60. Chiba T, Chang MY, Wang S, Wight TN, McMillen TS, Oram JF, et al. Serum amyloid A facilitates the binding of high-density lipoprotein from mice injected with lipopolysaccharide to vascular proteoglycans. Arterioscler Thromb Vasc Biol. 2011; 31: 1326-32.

61. Huang Y, DiDonato JA, Levison BS, Schmitt D, Li L, Wu Y, et al. An abundant dysfunctional apolipoprotein A1 in human atheroma. Nat Med. 2014; 20: 193-203.

62. Nicholls S, Ray K, Ballantyne C, Beacham L, Miller D, Ruotolo $\mathrm{G}$, et al. Comparative effects of cholesteryl ester transfer protein inhibition, statin and ezetimibe therapy on atherogenic and protective lipid factors: The accentuate trial. Atherosclerosis. 2016; 252: e237-8

63. Williams KJ, Fisher EA. Apolipoprotein-B: the crucial protein of atherogenic lipoproteins. In: Wang $\mathrm{H}$, Patterson $\mathrm{C}$, editors. Atherosclerosis: risks, mechanisms, \& therapies. Hoboken: John Wiley \& Sons; 2015. p.291 - 312

64. Violi F, Pignatelli P, Basili S. Nutrition, supplements, and vitamins in platelet function and bleeding. Circulation. 2010; 121: 1033-44.
65. Violi F, Carnevale R, Loffredo L, Pignatelli P, Gallin JI. NADPH Oxidase-2 and atherothrombosis. Insight from Chronic Granulamatous Disease. Arterioscler Thromb Vasc Biol. 2017; 37: 218-25.

66. Kinscherf R, Claus R, Deigner HP, Nauen O, Gehrke C, Hermetter A, et al. Modified low density lipoprotein delivers substrate for ceramide formation and stimulates the sphingomyelin-ceramide pathway in human macrophages. FEBS Lett. 1997; 405: 55-9.

67. Mukhin DN, Chao FF, Kruth HS. Glycosphingolipid accumulation in the aortic wall is another feature of human atherosclerosis. Arterioscler Thromb Vasc Biol. 1995; 15: 1607-15.

68. Chatterjee SB, Dey S, Shi WY, Thomas K, Hutchins GM Accumulation of glycosphingolipids in human atherosclerotic plaque and unaffected aorta tissues. Glycobiology. 1997; 7: 57-65.

69. Martin SF, Williams N, Chatterjee S. Lactosylceramide is required in apoptosis induced by N-Smase. Glycoconj J. 2006; 23: 147-57.

70. Kolmakova A, Kwiterovich P, Virgil D, Alaupovic P, Knight-Gibson $\mathrm{C}$, Martin SF, et al. Apolipoprotein C-I induces apoptosis in human aortic smooth muscle cells via recruiting neutral sphingomyelinase. Arterioscler Thromb Vasc Biol. 2004; 24: 264-9.

71. Slowik MR, De Luca LG, Min W, Pober JS. Ceramide is not a signal for tumor necrosis factor-induced gene expression but does cause programmed cell death in human vascular endothelial cells. Circ Res. 1996; 79: 736-47

72. Mu H, Wang X, Wang H, Lin P, Yao Q, Chen C. Lactosylceramide promotes cell migration and proliferation through activation of ERK1/2 in human aortic smooth muscle cells. Am J Physiol Heart Circ Physiol. 2009; 297: H400-8.

73. Edsfeldt A, Duner P, Stahlman M, Mollet IG, Asciutto G, Grufman $\mathrm{H}$, et al. Sphingolipids contribute to human atheroschlerotic plaque inflammation. Arterioscler Thromb Vasc Biol. 2016; 36: 1132-40.

74. Orsini F, Cremona A, Arosio P, Corsetto PA, Montorfano G, Lascialfari A, et al. Atomic force microscopy imaging of lipid rafts of human breast cancer cells. Biochim Biophys Acta. 2012; 1818: 2943-9.

75. Shaw AS. Lipid rafts: now you see them, now you don't. Nat Immunol. 2006; 7: 1139-42.

76. Pike LJ. Rafts de ned: a report on the Keystone Symposium on Lipid Rafts and Cell Function. J Lipid Res. 2006; 47: 1597-8.

77. Simons K, Ikonen E. Functional rafts in cell membranes. Nature. 1997; 387: 569-72

78. Anderson RG. The caveolae membrane system. Annu Rev Biochem 1998; 67: 199-225.

79. Brown DA, London E. Functions of lipid rafts in biological membranes. Annu Rev Cell Dev Biol. 1998; 14: 111-36.

80. Fielding CJ, Fielding PE. Membrane cholesterol and the regulation of signal transduction. Biochem Soc Trans. 2004; 32: 65-9.

81. Chetty PS, Mayne L, Lund-Katz S, Stranz D, Englander SW, Phillips MC. Helical structure and stability in human apolipoprotein A-I by hydrogen exchange and mass spectrometry. Proc Natl Acad Sci USA. 2009; 106: 19005-10.

82. Sorci-Thomas M, Thomas MJ. Microdomains, inflammation and atherosclerosis. Circ Res. 2016; 118: 679-91.

83. Foks AC, Lichtman AH, Kuiper J. Treating atherosclerosis with regulatory T cells. Arterioscler Thromb Vasc Biol. 2015; 35: 280-7.

84. Subramanian M, Thorp E, Hansson GK, Tabas I. Treg-mediated suppression of atherosclerosis requires MYD88 signaling in DCs. J Clin Invest. 2013; 123: 17988.

85. Ait-Oufella H, Sage AP, Mallat Z, Tedgui A. Adaptive (T and B cells) immunity and control by dendritic cells in atherosclerosis. Circ Res. 2014; 114: 1640-60. 
86. Dixon AM, Drake L, Hughes KT, Sargent E, Hunt D, Harton JA, et al. Differential transmembrane domain GXXXG motif pairing impacts major histocompatibility complex (MHC) class II structure. J Biol Chem. 2014; 289: 11695-703.

87. Anderson HA, Roche PA. MHC class II association with lipid rafts on the antigen presenting cell surface. Biochim Biophys Acta. 2015; 1853: 775-80.

88. Dubland JA, Francis GA. Lysosomal acid lipase: at the crossroads of normal and atherogenic cholesterol metabolism. Front Cell Dev Biol. 2015; 3: 3. doi: 10.3389/fcell.2015.00003.

89. Jelinek D, Patrick SM, Kitt KN, Chan T, Francis GA, Garver WS. Physiological and coordinate downregulation of the NPC1 and NPC2 genes are associated with the sequestration of LDL-derived cholesterol within endocytic compartments. J Cell Biochem. 2009; 108: 1102-16.

90. Ghosh S. Early steps in reverse cholesterol transport: cholesteryl ester hydrolase and other hydrolases. Curr Opin Endocrinol Diabetes Obes. 2012; 19: 136-41.

91. Ghosh S. Macrophage cholesterol homeostasis and metabolic diseases: critical role of cholesteryl ester mobilization. Expert Rev Cardiovasc Ther. 2011; 9: 329-40.

92. Moore KJ, Sheedy FJ, Fisher EA. Macrophages in atherosclerosis: a dynamic balance. Nat Rev Immunol. 2013; 13: 709-21

93. Neufeld EB, O’Brien K, Walts AD, Stonik JA, Malide D, Combs CA, et al. The human ABCG1 transporter mobilizes plasma membrane and late endosomal non-sphingomyelin-associated-cholesterol for efflux and esterification. Biology. 2014; 3: 866-91.

94. Ito A, Hong C, Rong X, Zhu X, Tarling EJ, Hedde PN, et al. Lxrs link metabolism to in ammation through abca1-dependent regulation of membrane composition and tlr signaling. Elife. 2015; 4: e08009. doi: 10.7554/eLife.08009.

95. Weber C, Noels H. Atherosclerosis: current pathogenesis and therapeutic options. Nat Med. 2011; 17: 1410-22.

96. Lippi G, Franchini M, Targher G. Arterial thrombus formation in cardiovascular disease. Nat Rev Cardiol. 2011; 8: 502-12.

97. Doring Y, Soehnlein O, Weber C. Neutrophil extracellular Traps in atherosclerosis and atherothrombosis. Circ Res. 2017; 120: 736-43.

98. Döring Y, Drechsler M, Soehnlein O, Weber C. Neutrophils in atherosclerosis: from mice to man. Arterioscler Thromb Vasc Biol. 2015; 35: 288-95.

99. Moreno JA, Ortega-Gómez A, Delbosc S, Beaufort N, Sorbets $\mathrm{E}$, Louedec L, et al. In vitro and in vivo evidence for the role of elastase shedding of CD163 in human atherothrombosis. Eur Heart J. 2012; 33: 252-63.

100. Soehnlein O. Multiple roles for neutrophils in atherosclerosis. Circ Res. 2012; 110: 875-88.

101. Moore KJ, Tabas I. Macrophages in the pathogenesis of atherosclerosis. Cell. 2011; 145: 341-55.

102. Hansson GK, Libby P, Tabas I. Inflammation and plaque vulnerability. J Intern Med. 2015; 278: 483-93.

103. Sakakura K, Nakano M, Otsuka F, Ladich E, Kolodgie FD, Virmani R. Pathophysiology of atherosclerosis plaque progression. Heart Lung Circ. 2013; 22: 399-411.

104. Yahagi K, Kolodgie FD, Otsuka F, Finn AV, Davis HR, Joner M, et al. Pathophysiology of native coronary, vein graft, and in-stent atherosclerosis. Nat Rev Cardiol. 2016; 13: 79-98.

105. Kavuma MM, Rayner KJ, Karunakaran D. The walking dead: macrophage inflammation and death in atherosclerosis. Curr Opin Lipidol 2017; 28: 92-8.

106. Stary HC. Natural history and histological classification of atherosclerotic lesions: an update. Arterioscler Thromb Vasc Biol. 2000; 20: 1177-8.
107. Virmani R, Kolodgie FD, Burke AP, Farb A, Schwartz SM. Lessons from sudden coronary death: a comprehensive morphological classification scheme for atherosclerotic lesions. Arterioscler Thromb Vasc Biol. 2000; 20: 1262-75.

108. Simionescu N, Vasile E, Lupu F, Popescu G, Simionescu M. Prelesional events in atherogenesis. Accumulation of extracellular cholesterol-rich liposomes in the arterial intima and cardiac valves of the hyperlipidemic rabbit. Am J Pathol. 1986; 123: 109-25.

109. Ross R, Glomset JA. Atherosclerosis and the arterial smooth muscle cell: Proliferation of smooth muscle is a key event in the genesis of the lesions of atherosclerosis. Science. 1973; 180: 1332-9.

110. Ross R, Glomset JA. The pathogenesis of atherosclerosis (first of two parts). N Engl J Med. 1976; 295: 369-77.

111. Ross R. George Lyman Duff Memorial Lecture. Atherosclerosis: a problem of the biology of arterial wall cells and their interactions with blood components. Arteriosclerosis. 1981; 1: 293-311.

112. Ross R. The pathogenesis of atherosclerosis-an update. N Engl J Med. 1986; 314: 488-500.

113. Ross R. The pathogenesis of atherosclerosis: a perspective for the 1990s. Nature. 1993; 362: 801-9.

114. Tabas I, García-Cardeña G, Owens GK. Recent insights into the cellular biology of atherosclerosis. J Cell Biol. 2015; 209: 13-22.

115. Libby P. In ammation in atherosclerosis. Nature. 2002; 420: 868-74.

116. Hansson GK. In ammation, atherosclerosis, and coronary artery disease. N Engl J Med. 2005; 352: 1685-95.

117. Hansson GK, Libby P. The immune response in atherosclerosis: a double-edged sword. Nat Rev Immunol. 2006; 6: 508-19.

118. Davies MJ. Stability and instability: two faces of coronary atherosclerosis. The Paul Dudley White Lecture 1995. Circulation. 1996; 94: 2013-20.

119. Schwartz SM, Galis ZS, Rosenfeld ME, Falk E. Plaque rupture in humans and mice. Arterioscler Thromb Vasc Biol. 2007; 27: 70513.

120. Fuster V, Moreno PR, Fayad ZA, Corti R, Badimon JJ. Atherothrombosis and high-risk plaque: part I: evolving concepts. J Am Coll Cardiol. 2005; 46: 937-54.

121. Libby P. Mechanisms of acute coronary syndromes. N Engl J Med. 2013; 369: 883-4.

122. Quillard T, Araújo HA, Franck G, Shvartz E, Sukhova G, Libby P. TLR2 and neutrophils potentiate endothelial stress, apoptosis and detachment: implications for super cial erosion. Eur Heart J. 2015; 36: 1394-404.

123. Gimbrone MA Jr. Vascular Endothelium in Hemostasis \& Thrombosis. Edinburgh: Churchill Livingstone; 1986.

124. Gimbrone MA Jr. Vascular endothelium in health \& disease. In: Haber E, ed. Molecular Cardiovascular Medicine. New York: Scientific American; 1995. p.49-62.

125. Harrison D, Griendling KK, Landmesser U, Hornig B, Drexler H. Role of oxidative stress in atherosclerosis. Am J Cardiol. 2003; 91: 7-11.

126. Gimbrone MAJ. Endothelial Dysfunction and the Pathogenesis of Atherosclerosis, Proceedings of the Fifth International Symposium. New York: Springer-Verlag; 1980.

127. Gimbrone MA Jr. Vascular endothelium and atherosclerosis. In: Moore S, ed. Vascular Injury and Atherosclerosis. New York: Marcel Dekker; 1981. p.25-52.

128. Gimbrone MA. Atherogenesis: current concepts. In: Schoen FJ, Gimbrone MA Jr, ed. Cardiovascular Pathology: Clincopathologic Correlations and Pathogenic Mechanisms. Baltimore: William \& Wilkens; 1995. p.1-11.

129. Atkins GB, Simon DI. Interplay between NF- $\kappa B$ and Kruppel-like factors in vascular in ammation and atherosclerosis: location, 
location, location. J Am Heart Assoc. 2013; 2: e000290. doi: 10.1161/JAHA.113.000290.

130. Lin Z, Natesan V, Shi H, Dong F, Kawanami D, Mahabeleshwar GH, et al. Kruppel-like factor 2 regulates endothelial barrier function. Arterioscler Thromb Vasc Biol. 2010; 30: 1952-9.

131. Doddaballapur A, Michalik KM, Manavski Y, Lucas T, Houtkooper $\mathrm{RH}$, You X, et al. Laminar shear stress inhibits endothelial cell metabolism via KLF2-mediated repression of PFKFB3. Arterioscler Thromb Vasc Biol. 2015; 35: 137-45.

132. Hergenreider E, Heydt S, Tréguer K, Boettger T, Horrevoets AJ, Zeiher AM, et al. Atheroprotective communication between endothelial cells and smooth muscle cells through miRNAs. Nat Cell Biol. 2012; 14: 249-56.

133. Moyes AJ, Khambata RS, Villar I, Bubb KJ, Baliga RS, Lumsden $\mathrm{NG}$, et al. Endothelial C-type natriuretic peptide maintains vascular homeostasis. J Clin Invest. 2014; 124: 4039-51.

134. Atkins GB, Wang Y, Mahabeleshwar GH, Shi H, Gao H, Kawanami $\mathrm{D}$, et al. Hemizygous deficiency of Krüppel-like factor 2 augments experimental atherosclerosis. Circ Res. 2008; 103: 690-3.

135. Dai G, Vaughn S, Zhang Y, Wang ET, Garcia-Cardena G, Gimbrone MA Jr. Biomechanical forces in atherosclerosis-resistant vascular regions regulate endothelial redox balance via phosphoinositol 3-kinase/Akt-dependent activation of Nrf2. Circ Res. 2007; 101: 723-33.

136. Hsieh CY, Hsiao HY, Wu WY, Liu CA, Tsai YC, Chao YJ, et al. Regulation of shear-induced nuclear translocation of the Nrf2 transcription factor in endothelial cells. J Biomed Sci. 2009; 16: 12. doi: 10.1186/1423-0127-16-12.

137. Blagovic K, Kim LY, Voldman J. Microfluidic perfusion for regulating diffusible signaling in stem cells. PLoS One. 2011; 6: e22892. doi: 10.1371/journal.pone.0022892

138. Zakkar M, Van der Heiden K, Luong le A, Chaudhury H, Cuhlmann S, Hamdulay SS, et al. Activation of Nrf2 in endothelial cells protects arteries from exhibiting a proinflammatory state. Arterioscler Thromb Vasc Biol. 2009; 29: 1851-7.

139. Fledderus JO, Boon RA, Volger OL, Hurttila H, Ylä-Herttuala S, Pannekoek $\mathrm{H}$, et al. KLF2 primes the anti-oxidant transcription factor Nrf2 for activation in endothelial cells. Arterioscler Thromb Vasc Biol. 2008; 28: 1339-46.

140. Boon RA, Horrevoets AJ. Key transcriptional regulators of the vasoprotective effects of shear stress. Hamostaseologie. 2009; 29: 39-43.

141. Heo KS, Le NT, Cushman HJ, Giancursio CJ, Chang E, Woo $\mathrm{CH}$, et al. Disturbed flow-activated p90RSK kinase accelerates atherosclerosis by inhibiting SENP2 function. J Clin Invest. 2015; 125: $1299-310$.

142. Heo KS, Chang E, Le NT, Cushman H, Yeh ET, Fujiwara K, et al. De-SUMOylation enzyme of sentrin/SUMO-speci c protease 2 regulates disturbed flow-induced SUMOylation of ERK5 and p53 that leads to endothelial dysfunction and atherosclerosis. Circ Res. 2013; 112: 911-23.

143. Woo CH, Shishido T, McClain C, Lim JH, Li JD, Yang J, et al. Extracellular signal-regulated kinase 5 SUMOylation antagonizes shear stress-induced anti-inflammatory response and endothelial nitric oxide synthase expression in endothelial cells. Circ Res. 2008; 102: $538-45$

144. Liu B, Shuai K. Targeting the PIAS1 SUMO ligase pathway to control inflammation. Trends Pharmacol Sci. 2008; 29: 505-9.

145. Lerchenmüller C, Heißenberg J, Damilano F, Bezzeridis VJ, Krämer I, Bochaton-Piallat ML, et al. S100A6 regulates endothelial cell cycle progression by attenuating antiproliferative signal transducers and activators of transcription 1 signaling. Arterioscler Thromb Vasc Biol. 2016; 36: 1854-67.
146. Bennett MR, Sinha S, Owens GK. Vascular smooth muscle cells in atherosclerosis. Circ Res. 2017; 118: 692-702.

147. Libby P, Ridker PM, Hansson GK. Progress and challenges in translating the biology of atherosclerosis. Nature. 2011; 473: 317 25.

148. Bartel DP. MicroRNAs: target recognition and regulatory functions. Cell. 2009; 136: 215-33.

149. Guo H, Ingolia NT, Weissman JS, Bartel DP. Mammalian microRNAs pre- dominantly act to decrease target mRNA levels. Nature. 2010; 466: 835-40.

150. Valencia-Sanchez MA, Liu J, Hannon GJ, Parker R. Control of translation and mRNA degradation by miRNAs and siRNAs. Genes Dev. 2006; 20: 515-24

151. Baek D, Villén J, Shin C, Camargo FD, Gygi SP, Bartel DP. The impact of microRNAs on protein output. Nature. 2008; 455: 64-71.

152. Friedman RC, Farh KK, Burge CB, Bartel DP. Most mammalian mRNAs are conserved targets of microRNAs. Genome Res. 2009; 19: 92-105.

153. Goedeke L, Rotllan N, Canfrán-Duque A, Aranda JF, Ramírez CM, Araldi E, et al. MicroRNA-148a regulates LDL receptor and ABCA1 expression to control circulating lipoprotein levels. Nat Med. 2015; 21: 1280-9.

154. Wagschal A, Naja-Shoushtari SH, Wang L, Goedeke L, Sinha S, deLemos AS, et al. Genome-wide identication of microRNAs regulating cholesterol and triglyceride homeostasis. Nat Med. 2015; 21: 1290-7.

155. Tall AR, Yvan-Charvet L, Terasaka N, Pagler T, Wang N. HDL, ABC transporters, and cholesterol efflux: implications for the treatment of atherosclerosis. Cell Metab. 2008; 7: 365-75.

156. Gerin I, Clerbaux LA, Haumont O, Lanthier N, Das AK, Buran $\mathrm{CF}$, et al. Expression of miR-33 from an SREBP2 intron inhibits cholesterol export and fatty acid oxidation. J Biol Chem. 2010; 285 : 33652-61.

157. Horie T, Ono K, Horiguchi M, Nishi H, Nakamura T, Nagao K, et al. MicroRNA-33 encoded by an intron of sterol regulatory elementbinding protein 2 (Srebp2) regulates HDL in vivo. Proc Natl Acad Sci USA. 2010; 107: 17321-6.

158. Marquart TJ, Allen RM, Ory DS, Baldán A. miR-33 links SREBP-2 induction to repression of sterol transporters. Proc Natl Acad Sci USA. 2010; 107: 12228-32.

159. Naja-Shoushtari SH, Kristo F, Li Y, Shioda T, Cohen DE, Gerszten RE, et al. MicroRNA-33 and the SREBP host genes cooperate to control cholesterol homeostasis. Science. 2010; 328: 1566-9.

160. Ramirez CM, Dávalos A, Goedeke L, Salerno AG, Warrier N, CireraSalinas D, et al. MicroRNA-758 regulates cholesterol efflux through posttranscriptional repression of ATP-binding cassette transporter A1. Arterioscler Thromb Vasc Biol. 2011; 31: 2707-14.

161. Sun D, Zhang J, Xie J, Wei W, Chen M, Zhao X. MiR-26 controls LXR-dependent cholesterol efflux by targeting ABCA1 and ARL7. FEBS Lett. 2012; 586: 1472-9.

162. Kim J, Yoon H, Ramírez CM, Lee SM, Hoe HS, Fernández-Hernando $\mathrm{C}$, et al. MiR-106b impairs cholesterol efflux and increases $\mathrm{A} \beta$ levels by repressing ABCA1 expression. Exp Neurol. 2012; 235: 476-83.

163. de Aguiar Vallim TQ, Tarling EJ, Kim T, Civelek M, Baldán Á, Esau C, et al. MicroRNA-144 regulates hepatic ATP binding cassette transporter A1 and plasma high-density lipoprotein after activation of the nuclear receptor farnesoid X receptor. Circ Res. 2013; 112: 1602-12.

164. Ramírez CM, Goedeke L, Rotllan N, Yoon JH, Cirera-Salinas D, Mattison JA, et al. MicroRNA 33 regulates glucose metabolism. Mol Cell Biol. 2013; 33: 2891-902. 
165. Zhang M, Wu JF, Chen WJ, Tang SL, Mo ZC, Tang YY, et al. MicroRNA-27a/b regulates cellular cholesterol efflux, influx and esterification/hydrolysis in THP- 1 macrophages. Atherosclerosis. 2014; 234: 54-64.

166. Chen T, Huang Z, Wang L, Wang Y, Wu F, Meng S, et al. MicroRNA$125 \mathrm{a}-5 \mathrm{p}$ partly regulates the inflammatory response, lipid uptake, and ORP9 expression in oxLDL-stimulated monocyte/macrophages. Cardiovasc Res. 2009; 83: 131-9. h

167. Yang K, He YS, Wang XQ, Lu L, Chen QJ, Liu J, et al. MiR146a inhibits oxidized low-density lipoprotein-induced lipid accumulation and inflammatory response via targeting toll-like receptor 4. FEBS Lett. 2011; 585: 854-60.

168. Tian FJ, An LN, Wang GK, Zhu JQ, Li Q, Zhang YY, et al. Elevated microRNA-155 promotes foam cell formation by targeting HBP1 in atherogenesis. Cardiovasc Res. 2014; 103: 100-10.

169. Chen L, Yang G. Recent advances in circadian rhythms in cardiovascular system. Front Pharmacol. 2015; 6: 71. doi: 10.3389/ fphar.2015.00071.

170. Feng D, Lazar MA. Clocks, metabolism, and the epigenome. Mol Cell. 2012; 47: 158-67.

171. McAlpine CS, Swirsky FK. Circadian influence on metabolism and inflammation in atherosclerosis. Circ Res. 2016; 119: 131-41.

172. Scheiermann C, Kunisaki Y, Frenette PS. Circadian control of the immune system. Nat Rev Immunol. 2013; 13: 190-8.

173. Davidson AJ, London B, Block GD, Menaker M. Cardiovascular tissues contain independent circadian clocks. Clin Exp Hypertens. 2005; 27: 307-11.

174. McNamara P, Seo SB, Rudic RD, Sehgal A, Chakravarti D, FitzGerald GA. Regulation of CLOCK and MOP4 by nuclear hormone receptors in the vasculature: a humoral mechanism to reset a peripheral clock. Cell. 2001; 105: 877-89.

175. Nonaka H, Emoto N, Ikeda K, Fukuya H, Rohman MS, Raharjo SB, et al. Angiotensin II induces circadian gene expression of clock genes in cultured vascular smooth muscle cells. Circulation. 2001; 104: $1746-8$.

176. Rudic RD, McNamara P, Reilly D, Grosser T, Curtis AM, Price TS, et al. Bioinformatic analysis of circadian gene oscillation in mouse aorta. Circulation. 2005; 112: 2716-24.

177. Lin C, Tang X, Zhu Z, Liao X, Zhao R, Fu W, et al. The rhythmic expression of clock genes attenuated in human plaque-derived vascular smooth muscle cells. Lipids Health Dis. 2014; 13: 14. doi: 10.1186/1476-511X-13-14.

178. Nguyen KD, Fentress SJ, Qiu Y, Yun K, Cox JS, Chawla A. Circadian gene Bmal1 regulates diurnal oscillations of Ly6C(hi) inflammatory monocytes. Science. 2013; 341: 1483-8.

179. Boring L, Gosling J, Cleary M, Charo IF. Decreased lesion formation in CCR2-/- mice reveals a role for chemokines in the initiation of atherosclerosis. Nature. 1998; 394: 894-7.

180. Gu L, Okada Y, Clinton SK, Gerard C, Sukhova GK, Libby P, et al. Absence of monocyte chemoattractant protein-1 reduces atherosclerosis in low density lipoprotein receptor-deficient mice. Mol Cell. 1998; 2: 275-81.

181. Soehnlein O, Drechsler M, Döring Y, Lievens D, Hartwig H, Kemmerich $\mathrm{K}$, et al. Distinct functions of chemokine receptor axes in the atherogenic mobilization and recruitment of classical monocytes. EMBO Mol Med. 2013; 5: 471-81.

182. Viswambharan H, Carvas JM, Antic V, Marecic A, Jud C, Zaugg $\mathrm{CE}$, et al. Mutation of the circadian clock gene Per2 alters vascular endothelial function. Circulation. 2007; 115: 2188-95.

183. Steffens S, Winter C, Schloss MJ, Hidalgo A, Weber C, Soehnlein O. Circadian control of inflammatory processes in atherosclerosis and its complications. Arterioscler Thromb Vasc Biol. 2017; 37: 1022-8.
184. Kinlay S, Michel T, Leopold JA. The future of vascular biology and medicine. Circulation. 2016; 13: 2603-9.

185. Human Microbiome Project Consortium. Structure, function and diversity of the healthy human microbiome. Nature. 2012; 486: 207-14.

186. Tang WH, Hazen SL. The contributory role of gut microbiota in cardiovascular disease. J Clin Invest. 2014;124: 4204-11.

187. Wang Z, Klipfell E, Bennett BJ, Koeth R, Levison BS, Dugar B, et al. Gut flora metabolism of phosphatidylcholine promotes cardiovascular disease. Nature. 2011; 472: 57-63.

188. Gregory JC, Buffa JA, Org E, Wang Z, Levison BS, Zhu W, et al. Transmission of atherosclerosis susceptibility with gut microbial transplantation. J Biol Chem. 2015; 290: 5647-60.

189. Albenberg LG, Wu GD. Diet and the intestinal microbiome: associations, functions, and implications for health and disease. Gastroenterology. 2014; 146: 1564-72.

190. Garrido AM, Bennett M. Assessment and consequences of cell senescence in atherosclerosis. Curr Opin Lipidol. 2016; 27: 431-8.

191. Coppe JP, Desprez PY, Krtolica A, Campisi J. The senescenceassociated secretory phenotype: the dark side of tumor suppression. Annual Rev Pathol. 2010; 5: 99-118.

192. Kang TW, Yevsa T, Woller N, Hoenicke L, Wuestefeld T, Dauch D, et $a l$. Senescence surveillance of premalignant hepatocytes limits liver cancer development. Nature. 2011; 479: 547-51.

193. Krizhanovsky V, Yon M, Dickins RA, Hearn S, Simon J, Miething C, et al. Senescence of activated stellate cells limits liver fibrosis. Cell. 2008; 134: 657-67.

194. Xue W, Zender L, Miething C, Dickins RA, Hernando E, Krizhanovsky $\mathrm{V}$, et al. Senescence and tumour clearance is triggered by p53 restoration in murine liver carcinomas. Nature. 2007; 445: 656-60.

195. Iannello A, Thompson TW, Ardolino M, Lowe SW, Raulet DH. p53dependent chemokine production by senescent tumor cells supports NKG2D-dependent tumor elimination by natural killer cells. J Exp Med. 2013; 210: 2057-69.

196. Acosta JC, O’Loghlen A, Banito A, Guijarro MV, Augert A, Raguz $\mathrm{S}$, et al. Chemokine signaling via the CXCR2 receptor reinforces senescence. Cell. 2008; 133: 1006-18.

197. Kuilman T, Michaloglou C, Vredeveld LC, Douma S, van Doorn $\mathrm{R}$, Desmet CJ, et al. Oncogene-induced senescence relayed by an interleukin-dependent inflammatory network. Cell. 2008; 133: 1019-31.

198. Coppe JP, Kauser K, Campisi J, Beausejour CM. Secretion of vascular endothelial growth factor by primary human fibroblasts at senescence. J Biol Chem. 2006; 281: 29568-74.

199. Coppe JP, Patil CK, Rodier F, Sun Y, Muñoz DP, Goldstein J, et al. Senescence-associated secretory phenotypes reveal cellnonautonomous functions of oncogenic RAS and the p53 tumor suppressor. PLoS Biol. 2008; 6: e301. doi: 10.1371/journal. pbio.0060301.

200. Coppe JP, Rodier F, Patil CK, Freund A, Desprez PY, Campisi J, et al. Tumor suppressor and aging biomarker p16INK4a induces cellular senescence without the associated inflammatory secretory phenotype. J Biol Chem. 2011; 286: 36396-403.

201. Okuda K, Khan MY, Skurnick J, Kimura M, Aviv H, Aviv A. Telomere attrition of the human abdominal aorta: relationships with age and atherosclerosis. Atherosclerosis. 2000; 152: 391-8.

202. Chang E, Harley CB. Telomere length and replicative aging in human vascular tissues. Proc Natl Acad Sci USA. 1995; 92: 11190-4.

203. Matthews C, Gorenne I, Scott S, Figg N, Kirkpatrick P, Ritchie $\mathrm{A}$, et al. Vascular smooth muscle cells undergo telomere-based senescence in human atherosclerosis: effects of telomerase and oxidative stress. Circ Res. 2006; 99: 156-64. 
204. Wang J, Uryga AK, Reinhold J, Figg N, Baker L, Finigan A, et al. Vascular smooth muscle cell senescence \& promotes atherosclerosis and features of plaque vulnerability. Circulation. 2015; 132: 190919.

205. Gardner SE, Humphry M, Bennett MR, Clarke MC. Senescent vascular smooth muscle cells drive inflammation through an Interleukin-1alpha-dependent senescence-associated secretory phenotype. Arterioscler Thromb Vasc Biol. 2015; 35: 1963-74.

206. Aviv H, Khan MY, Skurnick J, Okuda K, Kimura M, Gardner J, et al. Age dependent aneuploidy and telomere length of the human vascular endothelium. Atherosclerosis. 2001; 159: 281-7.

207. Vasile E, Tomita Y, Brown LF, Kocher O, Dvorak HF. Differential expression of thymosin beta-10 by early passage and senescent vascular endothelium is modulated by VPF/ VEGF: evidence for senescent endothelial cells in vivo at sites of atherosclerosis. FASEB J. 2001; 15: 458-66.

208. Minamino T, Miyauchi H, Yoshida T, Ishida Y, Yoshida H, Komuro I. Endothelial cell senescence in human atherosclerosis: role of telomere in endothelial dysfunction. Circulation 2002; 105: $1541-4$.

209. Rajapakse AG, Yepuri G, Carvas JM, Stein S, Matter CM, Scerri I, et al. Hyperactive S6K1 mediates oxidative stress and endothelial dysfunction in aging: inhibition by resveratrol. PLoS One. 2011; 6: e19237. doi: 10.1371/journal.pone.0019237.

210. Yepuri G, Velagapudi S, Xiong Y, Rajapakse AG, Montani JP, Ming $\mathrm{X}-\mathrm{F}$, et al. Positive crosstalk between arginase-II and S6K1 in vascular endothelial inflammation and aging. Aging Cell. 2012; 11: 1005-16.

211. Wu Z, Yu Y, Liu C, Xiong Y, Montani JP, Yang Z, et al. Role of p38 mitogen-activated protein kinase in vascular endothelial aging: interaction with Arginase-II and S6K1 signaling pathway. Aging. 2015; 7: 70-81.

212. Gorenne I, Kavurma M, Scott S, Bennett M. Vascular smooth muscle cell senescence in atherosclerosis. Cardiovasc Res. 2006; 72: 9-17.

213. Wang JC, Bennett M. Aging and atherosclerosis: mechanisms, functional consequences, and potential therapeutics for cellular senescence. Circ Res. 2012; 111: 245-59.

214. Muñoz-Espín D, Serrano M. Cellular senescence: from physiology to pathology. Nat Rev Mol Cell Biol. 2014; 15: 482-96.

215. Childs BG, Baker DJ, Wijshake T, Conopver CA, Campisi J, van Deusen JM. Senescent intimal foam cells are deleterious at all stages of atherosclerosis. Science. 2016 354: 472-7.

216. Vaughan DE, Rai R, Khan SS, Eren M, Ghosh AK. Plasminogen activator inhibitor-1 is a marker and a mediator of senescence. Arterioscler Thromb Vasc Biol. 2017; 37: 1446-52.

217. National Institute of Health [Internet]. The Precision Medicine Initiative Cohort Program - Building a Research Foundation for 21st Century Medicine. Precision Medicine Initiative (PMI) Working Group Report to the Advisory Committee to the Director, NIH [updated 2015 Sep 17; cited 2016 Feb 21]. Available from: http://www.nih.gov/sites/default/les/research-training/initiatives/ pmi/pmi-working-group-report-20150917-2.pdf.

218. Natarajan P, O'Donnell CJ. Reducing cardiovascular risk using genomic information in the era of precision medicine. Circulation. 2016; 133: 1155-9.

219. Abifadel M, Varret M, Rabès JP, Allard D, Ouguerram K, Devillers $\mathrm{M}$, et al. Mutations in PCSK9 cause autosomal dominant hypercholesterolemia. Nat Genet. 2003; 34: 154-6.
220. Innerarity TL, Weisgraber KH, Arnold KS, Mahley RW, Krauss RM, Vega GL, et al. Familial defective apolipoprotein B-100: low density lipoproteins with abnormal receptor binding. Proc Natl Acad Sci USA. 1987; 84: 6919-23.

221. Goldstein JL, Basu SK, Brunschede GY, Brown MS. Release of low density lipoprotein from its cell surface receptor by sulfated glycosaminoglycans. Cell. 1976; 7: 85-95.

222. Do R, Stitziel NO, Won HH, Jørgensen AB, Duga S, Angelica Merlini $\mathrm{P}$, et al. NHLBI Exome Sequencing Project. Exome sequencing identifies rare LDLR and APOA5 alleles conferring risk for myocardial infarction. Nature. 2015; 518: 102-6.

223. Willer CJ, Schmidt EM, Sengupta S, Peloso GM, Gustafsson S, Kanoni S, et al. Discovery and refinement of loci associated with lipid levels. Nat Genet. 2013; 45: 1274-83.

224. Mega JL, Stitziel NO, Smith JG, Chasman DI, Caulfield MJ, Devlin $\mathrm{JJ}$, et al. Genetic risk, coronary heart disease events, and the clinical benefit of statin therapy: an analysis of primary and secondary prevention trials. Lancet. 2015; 385: 2264-71.

225. Lloyd-Jones DM, Nam BH, D’Agostino RB Sr, Levy D, Murabito $\mathrm{JM}$, Wang TJ, et al. Parental cardiovascular disease as a risk factor for cardiovascular disease in middle-aged adults: a prospective study of parents and offspring. JAMA. 2004; 291: 2204-11.

226. Di Angelantonio E, Sarwar N, Perry P, Kaptoge S, Ray KK, Thompson A, et al. Major lipids, apolipoproteins, and risk of vascular disease. JAMA. 2009; 302: 1993-2000.

227. Sarwar N, Danesh J, Eiriksdottir G, Sigurdsson G, Wareham N, Bingham S, et al. Triglycerides and the risk of coronary heart disease: 10,158 incident cases among 262,525 participants in 29 Western prospective studies. Circulation. 2007; 115: 450-8.

228. Erqou S, Kaptoge S, Perry PL, Di Angelantonio E, Thompson A, White IR, et al. Lipoprotein(a) concentration and the risk of coronary heart disease, stroke, and nonvascular mortality. JAMA. 2009; 302: 412-23.

229. Heller DA, de Faire U, Pedersen NL, Dahlén G, McClearn GE. Genetic and environmental influences on serum lipid levels in twins. N Engl J Med. 1993; 328: 1150-6.

230. Utermann G. The mysteries of lipoprotein(a). Science. 1989; 246: 904-10.

231. Clarke R, Peden JF, Hopewell JC, Kyriakou T, Goel A, Heath SC, et al. Genetic variants associated with $\mathrm{Lp}$ (a) lipoprotein level and coronary disease. N Engl J Med. 2009; 361: 2518-28.

232. Kamstrup PR, Tybjaerg-Hansen A, Steffensen R, Nordestgaard BG. Genetically elevated lipoprotein(a) and increased risk of myocardial infarction. JAMA. 2009; 301: 2331-9.

233. Thompson A, Gao P, Orfei L, Watson S, Di Angelantonio E, Kaptoge $\mathrm{S}$, et al. Lipoprotein-associated phospholipase $\mathrm{A}(2)$ and risk of coronary disease, stroke, and mortality: collaborative analysis of 32 prospective studies. Lancet. 2010; 375: 1536-44.

234. White HD, Held C, Stewart R, Tarka E, Brown R, Davies RY, et al. Darapladib for preventing ischemic events in stable coronary heart disease. N Engl J Med. 2014; 370: 1702-11.

235. O’Donoghue ML, Braunwald E, White HD, Lukas MA, Tarka E, Steg PG, et al. Effect of darapladib on major coronary events after an acute coronary syndrome: the SOLID-TIMI 52 randomized clinical trial. JAMA. 2014; 312: 1006-15.

236. Nurnberg ST, Zhang H, Hand NJ, Bauer RC, Saleheen D, Reilly MP, et al. From Loci to Biology: Functional Genomics of Genome-Wide Association for Coronary Disease. Circ Res. 2016; 118:586-606. 